Portland State University

PDXScholar

$5-1-1975$

\title{
Contrasting Cultural Orientations among the Indian, Chinese, and Euro-American Peoples and Some Effects on Intercultural Communication
}

Gregory See-Chay Chan

Portland State University

Follow this and additional works at: https://pdxscholar.library.pdx.edu/open_access_etds

Part of the Speech and Hearing Science Commons

Let us know how access to this document benefits you.

\section{Recommended Citation}

Chan, Gregory See-Chay, "Contrasting Cultural Orientations among the Indian, Chinese, and Euro-American Peoples and Some Effects on Intercultural Communication" (1975). Dissertations and Theses. Paper 2271.

https://doi.org/10.15760/etd.2268

This Thesis is brought to you for free and open access. It has been accepted for inclusion in Dissertations and Theses by an authorized administrator of PDXScholar. Please contact us if we can make this document more accessible: pdxscholar@pdx.edu. 
AN ABSTRACT OF THE THESIS OF Gregory See-Chay Chan for the Master of Arts in Speech Communication presented May 1, 1975. Title: Contrasting Cultural Orientations Among the Indian, Chinese, and Euro-American Peoples and Some Effects on Intercultural Communication.

APPROVED BY MEMBERS OF THE THESIS COMMITTEE:

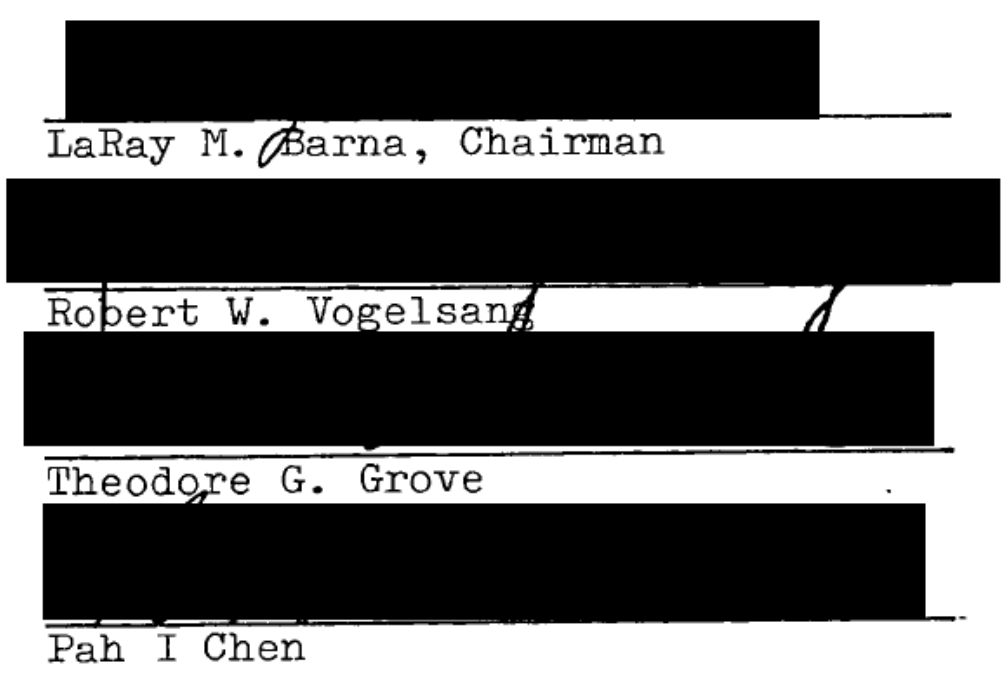

The purpose of this thesis is to lay the foundation for a better understanding between the East and the West by (1) a broad overview of the traditional value systems and thought patterns (sometimes referred to as cultural orientations) of the Indians, Chinese, and Euro-Americans, (2) comparing and contrasting these value systems and thought patterns, and (3) showing the effects of the contrasts of the Asian and Western cultural orientations on intercultural communication. 
The differences in the traditional heritages that affect the way that the three major cultures look at the world are discovered by drawing together descriptions from classical literature that have stood the test of time. The effects of the meaning of these contrasting cultural orientations on intercultural communication are discussed.

The terms "culture," "communication," "intercultural communication, " "cultural orientations," "thought patterns," "East" and "West" are defined.

A general review of the literature shows that the problem of intercultural communication is very complex, sophisticated, and has been present through history. Though philosophers, sociologists, psychologists, and communicators have attempted to show and be aware of the cultural differences, not much has been researched in terms of how these differences affect intercultural communication. Their only overwhelming concern is how people think at the moment of communication. They have usually ignored the nature of intercultural communication behaviors as the subsequent, natural response and expressions of cultural oriented thought patterns of the individuals.

An overview of the three major cultures is presented, followed by a comparison and contrast of the categories of will, activity, desire, progress, reason, attitude toward rhetoric, caste, distinctiveness, belief, change, and heroes; illustrations are then given of how these differences caused misunderstanding in the past. 
It is open to argument whether the "categorized" thought patterns are typical and applicable to contemporary events; however, examples are given to show some of these traditional attitudes and behaviors have influenced intercultural communication. 
CONTRASTING CUITURAI ORIENTATIONS AMONG THE INDIAN, CHINESE, AND EURO-AMERICAN PEOPLES AND SOME EFFECTS ON INTERCULTURAL COMMUNICATION

\author{
by \\ GREGORY SEE-CHAY CHAN
}

A thesis submitted in partial fulfillment of the requirements for the degree of

\author{
MASTER OF ARTS \\ in \\ SPEECH COMTUNICATION
}

Portland State University

1975 
TO THE OFFICE OF GRADUATE STUDIES AND RESEARCH:

The members of the Committee approve the thesis of Gregory See-Chay Chan presented May 1, 1975.

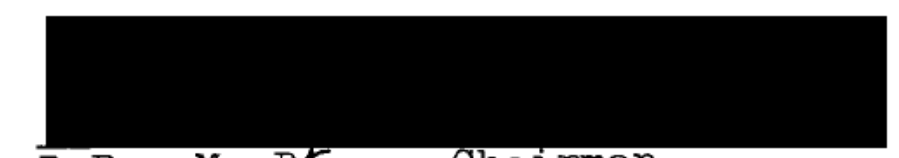

. LaRay M. Párna, Chairman

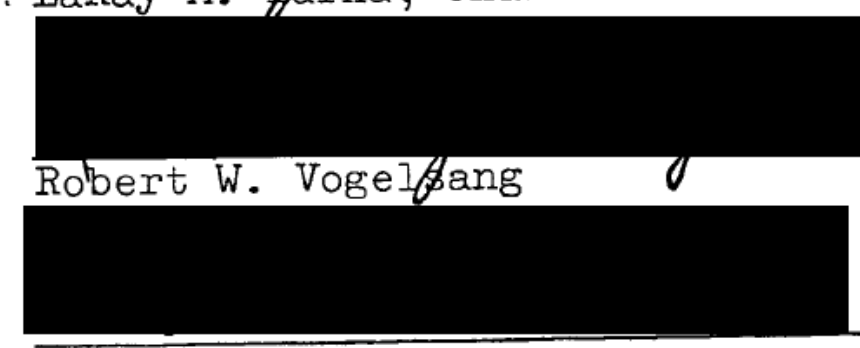

Theodore G. Grove

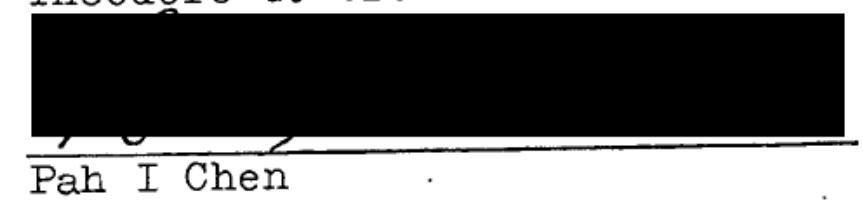

APPROVED :

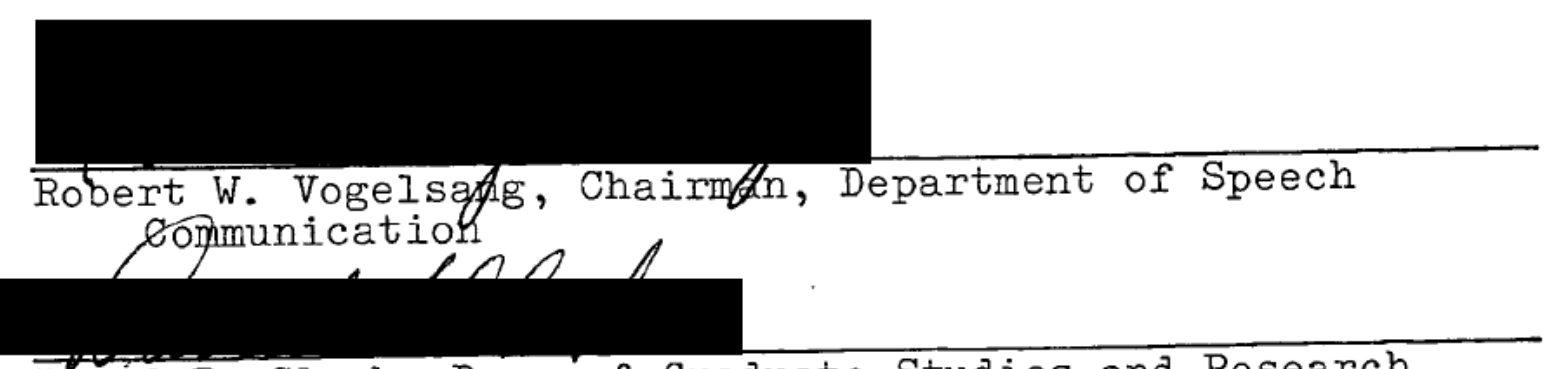

David T. Clark, Dean of Graduate Studies and Research 
Dedicated to

My most respected and honorable parents who brought me up and educated me with tremendous warmth through all the precarious winters of starvation, instability, cold, fear, and poverty; and cherished me with love through all the lovable and hopeful springs.

\section{Also to}

Hon. Mr. Gee-jung Leung (梁子珍)

who kindly sponsors me to further my study in the United States of America. 


\section{ACKNOWLEDGMENTS}

The author is much indebted to his graduate research and thesis advisor Professor LaRay M. Barna for her extreme patient and persistent advice and guidance in the course of the author's cultural accommodation to this country and later the writing of this thesis described herein. Without her instructive and advantageous encouragement this thesis could not have been completed. She sacrificed. two academic quarters and a whole summer vacation and tremendous efforts were made to help the author, especially during the sickness of Mr. Barna when she still stole a lot of time for the author in correcting and rephrasing the language of this manuscript. The author is also obliged to Dr. Robert Vogelsang, the Chairman of the Speech Communication Department, who always showed his deepest concern and consideration in the author's academic progress and cultural adjustment; and to Dr. Theodore Grove who also has always instructed the author with positive and empirical suggestions, and the author found it a great advantage to have been able to discuss the intercultural problems on an interpersonal level with him. The author has to thank Dr. Alfred Sugarman, not only for what he has learned from his great ideas in urban communication, but also he has allowed the author a share in 
the wealth of his knowledge by giving him a fund of information in response to his questions, and for his valuable help in connection with the English writing. The author found he has been benefited a lot from the advice of Dr. S. S. Sung (穼时選), the National Secretary-General of China Youth Corps, who taught him many ideas and concepts in promoting intercultural understanding and interracial love. The author is also indebted to Miss Hilda Kwan (臂慧孯) the Principal of St. Peter's College and former Headmistress of Shung Tak College of Hong Kong, who gave him all the help in his course of study, especially in times of failures, frustrations, and poverty. The author also thanked Mrs. Vogelsang who typed this thesis for him. 
TABLE OF CONTENTS

PAGE

ACKNOWLEDGMENTS . . . . . . . . . . . . . . . iv

CHAPTER

I INTRODUCTION . . . . . . . . . . I

Purpose ............ . . 2

Method ........... 3

Basic Assumption ....... . 3

Justification of the Study . . . . 3

II REVIEW OF IITERATURE AND DEFINITION OF TERMS

III OVERVIEW OF THE THREE MAJOR CULTURES:

INDIAN, CHINESE, AND EURO-AMERICAN • 24

Indian Civilization . . . . . . 26

Chinese Civilization ....... 33

Western Civilization ...... . 4l

IV INDIAN, CHINESE, AND EURO-AMERICAN VALUE

SYSTEEMS AND THOUGHT PATTERNS:

COMPARISON AND CONTRAST . . . . . 47

V APPITCATIONS . . . . . . . . . 95

VI SUMTARY . . . . . . . . . . 103

BIBLIOGRAPHY •. . . . . . . . . . . 107 


\section{CHAPTER I}

\section{INTRODUCT ION}

The distance that lies between the East and the West has shrunk. What takes place in Delhi, in Peking, in Tokyo, in Hong Kong, in Manila, is known the same day in London, in Paris, in Moscow, in Sydney, in Washington. A continuous stream of images and sounds flows back and forth; there is an inevitable coming together. Whether humanity likes it or not, a mechanical process is forcing the peoples of the world to assemble within a smaller enclosure. This necessitates intercultural communication, an important aspect in the present century.

Because of the new proximity, a new humanism is on the horizon. This time it will encompass all humanity. No longer can man nurture on Europe or America or Asia alone, nor can he still disregard the thought, the dreams, the experience, of one-half of humanity. Couchoid reports that this is the trend of today's philosophers by giving the examples of Roman Rolland, and Hermann Keyserling. ${ }^{1}$ Rolland says that there are a certain number of Westerners in Europe for whom civilization of Europe no longer satisfies them. Keyserling says that Europe no longer makes him react. It is too limited and familiar to him to 
give new shape to his being; he feels Europe today has no more than a single spirit and wishes to escape to spaces where his life will be transformed so that it will survive. Materlinck sets over against each other what he calls the "Western lobe" and the "Eastern lobe" of the human brain. He says,

The one produces reason, science, consciousness; the other secrets intuition, religion, the subconscious:. . More than once the East and the West have endeavoured to penetrate one another, to mingle, to work together, but the Western lobe, at least at the most active expanse of our globe, has heretofore paralysed and almost annihilated the effort of the other.

The Westerners have achieved extraordinary progress in all material science, but also catastrophes, such as the ecological problems that they are undergoing today. They, too, are looking forward to humanism. It is time to awaken the "paralyzed" Eastern lobe. It is time to communicate.

\section{PURPOSE}

The purpose of this thesis is to lay the foundation for a better understanding (better communication) between the East and the West by (1) a broad overview of the traditional value systems and thought patterns (sometimes referred to as cultural orientations) of the Indians, Chinese, and Euro-Americans, (2) comparing and contrasting these value systems and thought patterns, and (3) showing 
the effects of the contrasts of the Asian and Western cultural orientations on intercultural communication.

\section{METHOD}

The differences in the traditional heritages that affect the way that the three major cultures look at the world will be discovered by drawing together descriptions from classical literature that have stood the test of time. The effects of the meeting of these contrasting cultural orientations on intercultural communication will be discussed from the point of view of the author based on his own observation and his analysis and synthesis of the ideas of modern writers.

\section{BASIC ASSUMPTION}

The basic assumption of this thesis is that lack of knowledge of other people's cultural backgrounds and thought patterns impedes intercultural communication. Proof of this assumption is left to other authors, many of whom are listed in the bibliography.

IV. JUSTIFICATION OF THE STUDY

Now that forms of communication have brought the two halves of humanity face-to-face, this could either result in the greatest idea sharing of centuries, or, as professors in the contemporary field of study of intercultural communication fear, the existing communication barriers could pile 
higher. ${ }^{3}$ This is because the basic assumptions and patterns of thinking of each culture are usually so ingrained in its inhabitants that all other people are judged by them. Whether or not there will be understanding will depend on the extent to which each bothers to learn the other's culture, recognize each other's attitudes, attributes, and follow their avatars. Fortunately, some authorities, such as Maspero, feel Western man's curiosity is extensive and no more a passing fashion. It is linked up with a great spiritual current, the deepest and strongest that has touched, the Western world since the Renaissance. ${ }^{4}$

If successful intercultural communication is to occur, it is obvious there is need for research and analysis of the major cultures. There are several areas of weakness. For one, modern Western men, in the opinions of Max Scheler and Martin Buber, "have in their grip only the problematic side of men, while essential human nature slips through their fingers." 5 For example, students taking a course in intercultural communication studies tend to emphasize the problems' of intercultural communication rather than the nature of intercultural communication; students taking a course in religious studies tend to categorize and humanize religion, rather than to understand the nature of religion and how it affects human behavior and thought. Perhaps it is due to the development of technology and mechanical establishments in the Western world and because classical science 
and current philosophy overemphasizes the importance of the "isolated system" as a model of thought.

History tells us that there has been a lot of international conflicts between the East and the West due to communication misunderstandings rooted in ignorance of intercultural aspects. For example, Sir Pottinger, the British Royal Navy Commander in the Far East who later became the first Governor of the British Colony of Hong Kong, mistook the Chinese' most respectable ritual ceremony "kowtou" (kneeling in front of the elders or "mendates" or scholars) as an insult in 1841 and it was used as an excuse to start the Opium War in 1842. If he had learned of the traditions and cultural ceremonies of China this incident would not have triggered the war. As Porter says,

The chief barriers to intercultural communication come from errors in social perception, resulting from cultural variations that affect the process of perception. 6

More errors will compound as proximity increases between the East and the West. If the Chinese still ridiculously take the Americans as "Imperialists," the Americans still take the Russians as "enemies," the French still take the Indo-Chinese as their "subjects," the Belgians and the Portugese still arrogantly take the Africans as their "colonists," the British still proudly take the nonEnglishspeaking peoples as "uneducated," then more and more intercultural blocks will be built up between the East and the 
West on an interpersonal level. A foreign student from Africa in a university class of Communication Within the Minority Groups remarked that they are very different from the American blacks, and that the American blacks should not be called blacks any more. A student from the East in the cafeteria sneered loudly in front of a group of freshmen-foreign students that the Americans are mostly naive and stupid; a white student majoring in Speech Communication exaggerated with pride and bias that the Americans should teach the Africans more in the cultural ways because America is much better than the Africans in all fields. These remarks are real, heard on the campus every day.? They are typical examples of the intercultural barriers that exist and result in misunderstandings. 
Chapter 1--Notes

${ }^{I} \mathrm{~J}$. Hackin, "Introduction," in Asiatic Mythology, by Paul Louis-Couchoid (New York: Thomas Y. Crowell Company, 1972), pp. 1-9.

2 Ibid.

3 LaRay M. Barna, "Stumbling Blocks in Interpersonal Intercultural Communication, " in Intercultural Communication: A Reader, eds.: Larry A. Samovar and Richard E. Porter (Belmont, California: Wadsworth Publishing Co., Inc., 1972).

${ }^{4}$ Henriz Z. Maspero, "The Mythology of Modern China," in Asiatic Mythology, by Paul Louis-Couchoid, p. 250.

5 Thome H. Fang, "The Alienation of Man in Religion, Philosophy and Philosophical Anthropology, " Chinese Culture, pp. $1-3$.

$6_{\text {Richard }}$ E. Porter, "An Overview of Intercultural Communication," in Intercultural Communication: A Reader, p. 17.

7 Overheard by the author at Portland State University during his course of study 1973-74. 


\section{CHAPTER II}

\section{REVIEW OF LITERATURE AND DEFINITION OF TERMS}

Though there are numerous books of philosophy, psychology, and history talking about the origins of cultures, religions, and communications, there are not yet many printed materials discussing their practical relations to human communication behavior, especially in terms of intercultural communication. Though intercultural communication has become an important aspect in the contemporary world, not much research has been done to investigate the origins and development of one style of human interaction with another, or how human communication behaviors are related to the people's different cultural orientations. It seldom touches on how these differences affect intercultural communication: authorities report their perceptions and concepts and record their intercultural experiences, but they seldom try to discover what makes people behave in that way, or why they behave in that style. Their only overwhelming concern is how people think at the moment of communication. They have usually ignored the nature of intercultural 
communication behaviors as the subsequent, natural response and expressions of cultural oriented thought patterns of the individuals.

One book is a notable exception: Edward C. Stewart's American Cultural Patterns: A Cross-Cultural Perspective. ${ }^{1}$ As is stated in the Introduction of the book:

- . the approach has been to formulate the crosscuitural problems as differences between patterns of thinking, assumptions and values held by such Americans and those held by the foreigners with whom they work. These cultural differences often produce misunderstandings and lead to ineffectual activity in face-to-face communications. 2

In Part II of this same book the concepts of thinking, assumptions, and values are discussed with a view to dispelling the confusion which has surrounded the uses of these terms. In particular, a distinction is made between assumptions and values which have reference to actual behavior. In Part III American assumptions and values are provided: form of activity, form of relation to others, perception of the world and perception of the self. Part IV records some of the consequences of the cultural differences in the face-to-face interaction between Americans and their counterparts. Stewart says,

The theme of relativity of assumptions and values is stressed throughout the report by representing American culture characteristics in conjunction with the variations from other cultures or from American culture itself.3 
During the process of research, the author has been much benefited by an essay written by Professor Archie J. Bahm, "Eastern and Western Ideals: A Comparison. "4

The paper is divided into three main parts. Part I describes some of the general points of view of the traditional concepts in the East and the West. Part II talks about the differences of thought patterns of the European, Chinese, and Indian peoples. Part III concludes the author's assumption that "although comparisons should involve examination of both likenesses and differences, we tend to stress the differences and ignore the likenesses."

But Professor Bahm's essay does not touch the important aspect of how all his mentioned cultural ideals or patterns affect intercultural communication.

In the first two chapters of this thesis, the author is much indebted to the book Intercultural Communication: A Reader ${ }^{5}$ edited by Samovar and Porter. Many of the definitions, concepts, ideas, examples, and sources of references are taken from this book. It is a fact that this book gives good and clear ideas on intercultural communication though there is no specific discussion on intercultural communication between India, China, and the West. Robert T. Oliver refers to these problems in his two books Communication and culture $^{6}$ and Communication and culture in Ancient India and China.? 
Ruesch and Bateson emphasize the cultural aspect of communication $^{8}$ and Edward $T$. Hall opened up the nonverbal aspect in his books Silent Language ${ }^{9}$ and Hidden Dimension. 10 Many of the readings in Intercommunication Between Nations and Peoples $^{11}$ by Michael Prosser relate to the problem under consideration in this thesis as well as recent journal articles. 12 The newer basic speech texts are now including a chapter on intercultural communication. 13

\section{Definition of Terms}

The literature provides many definitions for the terms "culture," "communication," "intercultural communication," "cultural orientations," "thought patterns," "East," and "West."

Davison defines culture as group behaviorism. He says;

Culture is the sum total of the learned behaviors of a group of people which are generally considered to be the tradition of that people and are transmitted from generation to generation. 14

Paul Cardinal Yupin correlates culture with civilization. Each people has a way of living (in America they say the mode of life). Yupin calls this "civilization." The way people demonstrate their entity he calls "culture." To him, civilization means both material and spiritual aspects. Clothing, food, shelter, transportation, communication are typical focii of material progress. Spiritual civilization concerns itself with many components: 
language, literature, customs, beliefs, social forms, means of production, law, and education. Culture includes both aspects. 15

Porter defines culture as:

- . the cumulative deposit of knowledge, experience, meanings, beliefs, values, attitudes, religions, concepts of self, the universe, self-universe, relationships, heirarchies of status, role expectations, spatial relations, and time concepts acquired by a large group of people in the course of generations through individual and group strivings. Culture manifests itself both in patterns of language and thought and in forms of activity and behavior. These patterns of language and thought become models of common adaptative acts and styles of expressive behavior which enable people to live in a society within a given geographical environment at a given state of technical development.16

Hence, culture concerns a broad and unlimiting area of human activities and thoughts, but, as Porter has shown, a culture itself lies within geographical environments which affects individual people's activities and behaviors. All these cumulative cultural trends do not appear or form in an instant. The Western civilization, the Chinese civilization, the Indian civilization are all cumulative deposits of cultural developments. A European is not born with European culture, nor does a Chinese become a Confucianist if he is not oriented after his birth. An Indian is not born a Buddhist; he is influenced by the Indian religion. People are oriented in certain aspects when they are brought up in their cultures. Cultural traits and orientations are learned behaviors and thought patterns. 17 Edward Hall says, 
Culture is a word that has so many meanings already that one more can do it no harm. - . For anthropologists culture has long stood for the way of life of a people, for the sum of their learned behavior patterns, attitudes, and material things. Though they subscribe to this general view, most anthropologists tend to disagree however, on what the precise substance of culture is. In practice their work often leads some of them to a fascination with a single category of events among the many which make up human life, and they tend to think of this as the essence of all culture. Others, looking for a point of stability in the flux of society, often become preoccupied with identifying a common particle or element which can be found in every aspect of culture. In sum, though the concept of culture was first defined in print in 1871 by E. B. Taylor, after all these years it still lacks the rigorous specificity which characterizes many less revolutionary and useful ideas. 18

Though people have tried to define culture for many years, no unique definition has been accepted by all people. To have a universal admitted definition is less important that making known the importance of the role one's culture plays in interculturał, interpersonal communication.

What then is the meaning of communication?

According to Sitaram, communication is the act of understanding and being understood by the audience. 19 This points up that in the process of communication, there must be a giver and a receiver, or an encoder and a decoder. One man himself cannot communicate except to himself.

Kleinjans defines communication in this way: - . communication is the transmission of thought from one mind to others, and is one of the basic activities of the human race; it is a skill through which men make magnificent successes and 
startling failures, and art without which genius is dumb, power brutal and aimless. 20

Porter, in his "Social Psychological Factors:

What We Bring to Intercultural Communication," gives a very clear idea about communication. He asserts:

When we communicate, we have a purpose. It. usually is behavioral where, through the manipulation of symbols, we attempt to affect the behavior of others. To establish this, we must share certain commonalities, including the establishment of common meanings through the sharing of our perceptions.21

Berlo, in his the Process of Communication explains:

Communication does not consist of the transmission of meaning. Meanings are not transmitted, nor transferable. Only messages are tranmittable, and meanings are not in the message, they are in the message-user. 22

But Barnlund views communication as a search of meaning:

The aim of communication is to increase the number and consistency of our meanings within the limits set by patterns of evaluation that have proven successful in the past, our emerging needs and drives, and the demands of the physical and social setting of the moment. 23

Combining Berlo and Barnlund's ideas about communication, Porter and Samovar conclude:

As participators in a communication event, we bring numerous social psychological states with us that affect the social perception process. For instance we bring unique experiences, expectations, cognitions, beliefs, values, attitudes, thought processes, and perceptional faculties. What these are for each of us is largely a function of our particular culture. If we are communicating with someone from our culture, we bring similar social psychological states. In this case we only have to concern 
ourselves with individual variance within our culture. But, when communicating interculturally, our social psychological states are apt to be very different. Here the influence of more than one culture is present, and we must be alert to the fact that we bring very different states to the communication event. 24

Porter and Samovar have thus expanded the communication form from intraculture to interculture. By intercultural communication we mean communication between peoples of different cultures as opposed to communication between official representatives of nations, i.e., international communication. 25 In other words, it is the interaction between people of different cultures.

Porter and Samovar say:

In recent years the term "intercultural communication" has evolved to describe the form of interaction that takes place when speaker and listener come from different cultures. Although "intercultural communication" is often used synonymously with "cross-cultural communication," "trans-cultural communication," we believe "intercultural communication" to be the most suitable term because it describes all of the situations that exist when two or more communicators come from different cultures. Intercultural communication, thus viewed, involves cultural differences that transcend racial or ethnic differences. Whenever the parties to a communication act bring with them different experiential backgrounds that reflect a long-standing deposit of group experience, knowledge, and values, we have intercultural communication. It often involves racial or ethnic differences, or both, but we hold that intercultural communication also exists when there are gross socio-cultural differences without accompanying racial and ethnic differences. 26

Judging from what Porter and Samovar have said, there are three things one should be aware of in the process of 
intercultural communication: (I) the existing differences of culture, (2) different experiential backgrounds, and (3) socio-cultural differences without accompanying racial and ethnic differences.

Sitaram, in his "What is Intercultural Communication?" defines the term intercultural communication in this way:

Intercultural communication does not take place in a vacuum. It does take place in an environment which could be intracultural or interethnic or intercultural. It involves communicator and audience of entirely different to slightly different cultures.27

Jawaharlal Nehru gave a very good idea to better intercultural communication on an interpersonal level. He asserts,

If we seek to understand a people we have to put ourselves, as far as we can, in that particular historical and cultural background. . . One has to recognize that countries and people differ in approach and their ways, in their approach to life and their ways of thinking and living. In order to understand them we have to understand their way of life and approach. If we wish to convince them, we have to use their language as far as we can, not language in the narrow sense of the word, but the language of the mind.28

Since each person has a different background of education, and has been oriented in a specific way, each, then, has his own perception of other people. This is what Nehru said above; "In order to understand them we have to understand their way of life and approach." Also, groups of people acquire different cultural orientations as they are brought up in their own societies. 
Then what is "cultural orientations"? According to Burtt, there are four obvious and striking ways in which a cultural orientation develops. 29 The first and the foremost concerns the basic moral attitudes of men. Primitives, with the rarest of exceptions, feel no sense of moral obligation toward anyone outside of their small cultural group. Their feelings are freely expressed in their religion and their gods are the unknowns of the mystic universe. This is the origin of the culture's mythologies. With the development of a modern civilization, the people started to add. the moral aspects. Again, these aspects are usually expressed through their religious faith. The Westerners, the Chinese, and the Indians each developed their own moral standards which have become part of their life patterns.

The second development concerns man's basic conviction about the universe. Primitive thought takes for granted a cosmological pluralism. There are many and diverse powers, familiar or more elusive; there is no unity of force or law pervading them all. Civilized theology, philosophy, and science assume, however, an ultimate monism in the structure of things. There is a single source and determiner of all reality, or a single principle of order which gives systematic coherence to the modes of action that everything exists in the world.

The third concerns the conception of the human soul. Primitive ideas assume the soul is a physical or 
quasi-physical entity, identified with the breath that animates a living body or the shadow that it casts as it moves along the ground. The leaders of civilized religion abandon this notion, finding it hopelessly unsuited to their experience and their need. In accepting as valid a universal moral law, and in responding to the divine as interpreted in monistic law, they have ascribed to all men a spiritual capacity that constitutes the human soul--the power to respond in feeling and condixt to a supreme moral ideal and to realize harmony with a Divine Being embodying the ideal. This potency in man gives meaning to the civilized concept of "self" or "spirit." It is something invisible and nonmaterial but, nonetheless, makes up the core of one's responsibility. It is that in him which is most real and of greatest value.

The fourth area of a culture's orientation concerns the belief that is held with respect to the nature of natural happiness, the kind of experience in which man's true wellbeing and essential integrity lie. The typical primitive idea of happiness is quite simple. To them happiness consists of satisfying natural desires as fully and successfully as possible. There is no awareness that the part of one's personality which identifies with these instinctive drives may not be "self" but only an immature and in the long run inacceptable substitute for it. But the pioneers of 
civilized religion have discovered all these spontaneous cravings are not dependable guides to happiness; they are the causes of much misery and suffering, in oneself and in others. Civilized happiness consists of identifying with something that transcends these instinctive urges.

There is no doubt that all people have been oriented to the aspects of their own culture. It is likely that some kinds of cultural orientations may not be easily accepted by another cultural group. Oliver says,

The kinds of ideas that interest people and the reasons why they accept or reject them are not universal; they are particular attributes of specific cultures. 30

He also says,

Should we attempt to conceptualize the nature of rhetoric and of public discourse in Asia in terms that have proved appropriate in the West, the results would be biased, inadequate, and misleading. The East is not the West. Cultures differ, and minds, feelings, and intentions in different societies intermesh in different ways. - . Any attempt to discover in Asia prototypes of the Western rhetorical canons would be unavailing. It would resemble trying
to measure the salinity of water with a ruler.

Jowett, in his "Introduction to the 'Philebus," gives the following comment:

The world of knowledge is always dividing more and more; every truth is at first the enemy of every truth; yet without this division there can be no truth; nor any complete truth without the reunion of the parts into a whole. 32

Hall defines patterns as those implicit cultural rules by means of which sets are arranged so that they 
take on meaning. He admitted that too little has been known about thought patterns and how they operate. True, the rules which hold for many years and aspects of culture could be quoted, but there was no theory of patterning, no account of how one analyzes and describes patterns. 33

The terms "culture," "communication," "intercultural communication," "cultural orientations," and "thought patterns" have been defined. There remains two terms whose usage should be clarified: Asian and Western. In this thesis Eastern refers to India and China only. When Easterm culture or religion is mentioned, the reference is to Buddhism, Hinduism, Confucianism, and Taoism only. When the term Western is mentioned in this thesis, it refers to the European countries and the countries that have adherred to the European culture, such as the United States of America. When western culture is mentioned, it refers to the cultures that have the origins from Greek and Roman thoughts and Christianity. 
Chapter 2--Notes

IFdward C. Stewart, American Cultural Patterns: A Cross-Cultural Perspective, Regional Council for International Education (Pittsburgh, $\mathrm{Pa}$.: University of Pittsburgh, 1971).

$$
{ }^{2} \text { Ibid., p. 2. } 3 \text { Tbid. }
$$

${ }^{4}$ Archi J. Bahm, "Eastern and Western Ideals: A Comparison," University of New Mexico, 1973, p. 5.

${ }^{5}$ Larry A. Samovar and Richard E. Porter, eds., Intercultural Communication: A Reader (Belmont, California: Wadsworth Publishing Co., Inc., 1972).

$6_{\text {Robert T. Oliver, Communication and Culture }}$ (Syracuse, New York: Syracuse University Press, 1971).

7 Idem, Communication and Culture in Ancient India and China (Syracuse, New York: Syracuse University Press, 1972).

${ }^{8}$ Jurgen Ruesch, M.D., and Gregory Bateson, Communication: The Social Matrix of Psychiatry (New York, N.Y.: W. W. Norton and Co., Inc., 1968).

9dward T. Hall, The Silent Language (Greenwich, Conn.: Premier Publishing Company, Inc., 1959).

${ }^{10}$ Idem, The Hidden Dimension (Garden City, N.Y. : Doubleday and Company, Inc., 1966).

$11_{\text {Michael Prosser, Intercommunication Between Nations }}$ and Peoples (New York, San Francisco, London: Harper and Row Publishers, 1973).

${ }^{12}$ Santokh S. Anant, "Self and Mutual Perception of Salient Personality Traits of Different Caste Groups," Journal of Cross-Cultural Psychology, I, I (Spring, 1970), pp. 41-52; Lois Murphy and Gardner Murphy, "Perspectives in Cross-Cultural Research," Journal of Cross-Cultural Psychology, I, I (Spring, 1970), pp. 1-4; Berndt Brehmer, Hiroshi Azuma, Kenneth Hammond, Lubomir Kostron, and Kenis D. Varonas, "A Cross-National Comparison of Cognitive Conflict," Journal of Cross-Cultural Psychology, I, I (Spring, 1970), pp. 5-20. 
13 For example: K. S. Sitaram, "What is Intercultural Communication?" in Intercultural Communication: A Reader, eds.: Larry A. Samovar and Richard E. Porter; Vernon Jensen, Perspectus on Oral Communication (Boston: Holbrook Press, 1970).

14 Andrea I. Rich and Dennis M. Ogawa, "Analytical Approach to Intercultural Communication," cited by W. Phillips Davison, Interpersonal Political Communication (New York: Frederick A. Prager, 1965), p. 27.

${ }^{15}$ Paul Cardinal Yupin, "Comparison Between Eastern and Western Cultures," a lecture delivered at the Seminar on China Studies, June 22, 1973 at National Chenchi University, Taipei, Taiwan, Republic of China.

16 Richard E. Porter, "An Overview of International Communication," in Intercultural Communication: A Reader, p. 3 .

17 Hall, The Silent Language, p. 30.

${ }^{18}$ Ibid., p. 31. . $\quad{ }^{19}$ Sitaram, p. 19.

20 Everett Kleinjans, "Communication with Asia," in Intercultural Communication: A Reader, p. 257.

${ }^{21}$ Larry A. Samovar and Richard E. Porter, "Social Psychological Factors: What We Bring to Intercultural Communication," in Intercultural Communication: A Reader, p. 33.

22 David K. Berlo, The Process of Communication

(New York: Holt, Rinehart, and Winston, 1960), p. 175.

23 Dean C. Barnlund, "Toward a Meaning-Centered Philosophy of Communication, " Journal of Communication, 1, No. 12 (1966), pp. 200-201.

24 Samovar and Porter, "Social Psychological Factors: What We Bring to Intercultural Communication," p. 33.

25 Disler Luther, "The Adolescent 'Hippie' and the Emergence of a Matristic Culture," in Intercultural Communication: A Reader, pp. 362-371.

26 Samovar and Porter, "Introduction," p. 1.

27 Sitaram, p. 21 . 
28 Jawaharlal Nehru, cited by Larry A. Samovar and Richard E. Porter in Intercultural Communication: A Reader, p. 97 .

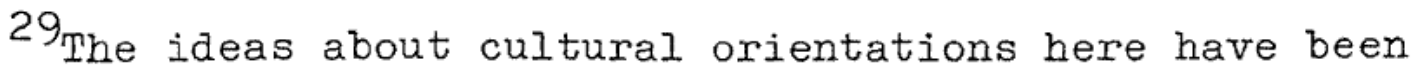
summarized from E. A. Burtt, The Teaching of the Compassionate Budaha (New York: Mentor, The New American Iibrary, 1955), pp. 13-15.

30 Oliver, Communication and Culture in Ancient India and China, pp. 2-7.

$3{ }^{1}$ Tbid.

${ }^{32}$ Carsun Chang, The Development of the Neo-Confucian Thought (New York: Bookman Associates, 1957), p. 9.

33 Hall, The Silent Language, p. 111. 


\section{CHAPTER III}

\section{OVERVIEW OF THE THREE MAJOR CULTURES: INDIAN, CHINESE, AND EURO-AMERICAN}

Before selecting specific aspects of the three major cultures to compare and contrast some general background is necessary.

Three-fourths of the subjects represented in the world civilizations are religious; ${ }^{I}$ to penetrate the heart of each culture we should begin with a knowledge of the basis of a culture: religion. When a Westerner is brought up in a Christian society "salvation" is his thematic concept in Iife and after-life; to an Indian living in a Buddhist society "going to the Buddha-Iand" is the searching goal in his whole life and, to a Confucian-oriented Chinese "live and die according to the natural code" is his lifelong dream and ideal. To the religious in the Eastern world, the creation of the gods is the most natural, the most secret, the slowest, the loftiest, of the works of man in the development of a world civilization. It is the supreme achievement of his profound experiences. How many thoughts and accumulated desires must go to make a god? The gods have no reality save a spiritual one, but this reality is superior to that of all the humble worshippers who give them life. ${ }^{2}$. In. 
the orchard of humanity they are the golden apples to which all sap flows and concentrates. The Westerners, with their spirits still "barbarian" and caught up with what the philosphers call realism, find it hard to comprehend the wisdom of the Eastern gods.

The Chinese adore their famous historical figures, the Indians worship their monks, and the Westerners respect their philosophers. These are good examples of the worshipping of gods made by themselves. That is why Rigveda has proclaimed that the mortal made the immortal. 3 An Indian monk in the sixth century of the Western era, said before the Emperor Leang Wu $\mathrm{Ti}$ of China that there is no Buddha outside the heart. Save the reality of the heart all is imaginary. The heart is the Buddha, the Buddha is the heart. 4 These three notables have expressed the genuine feelings of the Eastern people. These feelings have motivated a great deal of influence in the acts and beliefs of the Eastern people. To them, belief in Buddha means belief in the heart, the heart is the consciousness and the truth. When they want to do anything they first have to ask themselves whether the thing itself should be done under human consciousness. To a Western Christian, he would ask himself whether the act has been done in accordance with the will of God.

The reason why the Asians have to ask introspectively whether the thing should be done under human consciousness is that because the Asians, epitomized in the philosophies of 
Sakyamuni, Confucius, Mencius, and Lau-Tze, emphasize the concept of "asking-one's-own-consciousness." When a child does something wrong, his Asian parents would tell the child not to think of anything besides his consciousness. Though no one else knows what one is doing and thinking in private, his own heart knows. The demons around him know what he has been doing, and the earth and heaven know what is in one's mind. The parents often repeat this concept to the child. It is not served as a threatening incentive or painful initiation to the child, but rather it has become something passed down from generation to generation. "Don't think one can do something without being discovered by other people," has become an educational concept in the family. This concept to some extent coincides with the Christian concept "God is everywhere." No matter what kind of religion or culture a people has, when they can not answer something, they refer to the unknown or supernatural. This is one common characteristic of all peoples of all cultures.

\section{INDIAN CIVILIZATION 5}

India is the most religious country in the universe. The Indians are taught to live lives of gentleness, serenity, and compassion by means of liberation from selfish craving. These are the fundamental teachings of this great oriental 
culture, which originated from Buddhism. What "religious" means here is quite different from the Western churchgoers' interpretation which the Asians would deem not religious at all. The Indians are more devoted to heart and spirit; they seldom take up the strong missions to sell their religion by act and material.

Indians are taught to believe in two roles within their culture: the dynamic and the aescetic. ${ }^{6}$ The dynamic role exalts man's force and the other type is founded upon renunciation, "the cultural role of master" and the "cultural role of slave."7 These concepts are unfamiliar to the contemporary Westerners who adore democracy and freedom. They believe men are born equal and free, not slave or master. But in India, people do accept this concept of master-slave, and take their fate as something born to them. While a child grows, he is always taught the idea of unlimited perpetuality. His growing mind pursues detachment to the last fiber of soul. 8

Indians are taught that only the gods live in paradises of sensuous or intellectual delight; human beings have to live a more precarious life. If one suffers on this earth, he should not complain. He should be happy about it. It is through sufferings that he will be awarded a better life in the Buddha-Iand. So the goals of the Indians are built to catch up to the living of the gods--not in their lifetimes, 
but in their afterlives. They frequently live lives of compassion, and are serene and gentle. They are taught through the religious teachings not to commit crimes when they are living in this world, not to be tempted by evil or wicked will. Unlike the Western Christians, Indians like to live as they are, and death to them is just a point in the whole process of renunciation. There is no fear of the unavoidable death. Death is not a termination of life but rather a new phase of another life. By living lives of charity, devotion, and serenity they might become a god in their afterlife.

A man, if he has lived meritoriously in previous lives and in accordance with the law of retribution for deeds, will be allowed to attain absolute freedom. At that time, he will be rewarded with the privileges the gods have: omniscient, freed from passions, assured at his death that he can escape from transmigration; he will enter into Nirvana. This can be used to partially explain why the Indians live a pious life. Like Christianity, Buddhists believe that someday Buddha Maitreya will be sent to this world again and preach the doctrine and renew the dying faith. The Catholic missionaries knew this very well when they first came to preach to the Asian people. They made use of this religious likeness and preached the gospel of the foretelling of the savior, so they were quite successful 
in their missions. The Catholics admitted that the Great Budaha was a great prophet coming for Christ to prepare the path to salvation, and Confucius was the saint that first awakened the sinful people to do good.

No matter what the different cultures named their gods there is a common moral taught to the peoples of all cultures: one man's fate is ineluctably determined by the merits or the sins accumulated in the course of the ages. He is rich because he gave alms in a former life. He is hunchbacked for having mocked at an ascetic. He will suffer through the one he has ill-treated. Indian culture is of no exception to this area of morality.

Culturally, Indians are oriented with the following basic moral-religious teachings:

1. Indians are taught with an advanced and altruistic system of morality. One of the first steps on - the road to Nirvana is to do good to others, and thereby weaken the illusion of egocentricity which is the main cause of human sorrow. Basic is the four Noble Truths: (a) that all life is inevitably sorrowful, (b) that sorrow is due to craving, (c) that it can only be stopped by the stopping of craving, and (d) that this can only be done by a course of carefully disciplined and moral conduct, culminating in the life of concentration and meditation. Affected by these concepts, Indians view the living life as something not of happiness 
and joy. They come to this world to suffer, to taste the experience of sorrow. This is why the Indians "enjoy living in poverty."

2. Most of the Indians are taught to believe that all things in the universe may be classified into five components, or are composed of a mixture of them: form and matter, sensations, perceptions, psychic dispositions or constructions, and consciousness or conscious thought. The first consists of the objects of sense and various other elements of less importance. Sensations are the actual feelings arising as a result of the exercise of the six senses upon sense objects, and perceptions are the cognitions of such sensations. The psychic constructions include all various psychological emotions, propensities, faculties, and conditions of the individual, while conscious thought arises from the interplay of the other psychic constituents.

3. The Indians are very sensitive to the Nature of Consciousness and the Chain of Causation. The former is an appeal for an objective and clear realization that everything is dependent on causes outside itself and each becomes an enumeration of the elements of the Chain of Causation. The latter is to make people not to bother unduly about the question of the survival of the personality and then to realize that anything that happens in this world is of cause and effect. 
4. Indians emphasize the orientation of meritorious action. Right actions of a person comes first in his life. Right view is also important, but it is not so much emphasized. Whatever the beliefs of a man may be, his good deeds and self-discipline are an unfailing source of merit, and lead to a happier rebirth. This may give him the opportunity for further spiritual progress. The Mahayana teaches that the merit accruing from good deeds can be transferred by a voluntary act of will, and men are encouraged, by the example of the compassionate bodhisttvas, to make such transfers of merit.

5. The Indian literature does not lay down definite instructions on social or political life. It leaves the people to be dependents of the ministrations of the brahmans, and, instead of giving a lead in political and social matters, the Indian cultural leaders instructed the people to be willing to compromise with the existing ways of everyday life. Though in practice the Indians seem to have accepted the existence of a society with sharp class divisions and to have made no frontal attack on it, each class is respected for spiritual and moral merit.

No brahman is such by birth. No outcaste is such by birth. An outcaste is such by his deed 9 . 
6. Indians are so oriented that all their experience of the phenomenal world is like that of the shortsighted monk, in that all beings labor under the constant illusion of perceiving things where in fact there is only emptiness. This emptiness or Void is all that truly exists. The whole chain of existence is composed of a series of transitory events, but emptiness never changes. It is absolute truth and absolute being--in fact it is the same as Nirvana and the Body of Essence of the Buddha. Nothing in the phenomenal world has full being, and all is ultimately unreal. Therefore every rational theory about the world is a theory about something unreal evolved by an unreal thinker with unreal thoughts. Thus, by the same process of reasoning, every logical argument can be reduced to absurdity by a process. If the phenomenal world was ultimately unreal, then emptiness must be real. Though every logical proof of its existence was vitiated by the flaw of unreality, it could be experienced in meditation with a directness and certainty which the phenomenal world does not possess. It is one characteristic of the Indian cultural orientations that joy is one of the cardinal virtues of spiritual life; one has to train his mind that even in the most painful and unhappy situations it is still full of calm and inner joy. It is nonmaterial, or nonphysical. Though one lives in poverty he still has a piece of joyful 
heart.

He shares his riches with those afflicted by poverty. 10 He bears the burdens of those who are tired and weary. 10

The Indians are taught that passion is a means of salvation. At a certain stage of self-development, to give way to the passions, especially the sexual passions, is a positive help along the upward path.

- The mystic duly dwells On the manifold merits of his divinity, He delights in thoughts of passion, And by the enjoyment of passion is free. ${ }^{11}$

Understanding the cultural orientations of India, one gets to know that, as E. A. Burtt says,

All Asia received its cultural education from India. The Buddhism that India discarded pursued its destiny all around her. 12

\section{CHINESE CIVILIZATION}

As it has been mentioned, each culture has its own characteristics and so does China. China offers the example of a living popular culture in which Buddhism, Taoism, and Confucianism are finally fused together. Christianity might have been incorporated if the Jesuits in the time of the Emperor Kang Hsi had been doing a better job of crosscultural communication.

It is interesting that the cultural characteristics of modern China were formed in the course of the ages by 
juxtaposition of elements of varied origin: old native divinities, certain great figures of Buddhist epoch, and Taoist personages; and among them, Confucianism stands out alone as the main cultural stream in the development of Chinese cultural history.

For more than two millenia the pervasive influence of Confucianism was ever present. It molded the lives and the thought of men who created and perpetuated the civilization of China--a civilization that represents one of mankind's great efforts to build, rationalize, and adorn the good society. 13

Though Chinese are much influenced by Confucianism, nevertheless, it is often said that chinese have been oriented in three cultural origins: Confucianism, Buddhism, and Taoism. By this it is not meant that some are Confucians, some are Buddhists, and some are Taoists, but each Chinese is individually an adherent of the three religions at the same time. At first, he is no more capable than the Westerners of believing in several distinct religions at once. For example, this might require believing, as Buddhists, that there is no supreme god governing the universe (the gods being mediocre beings of limited power, subject to birth and death, inferior to the Buddhas who have attained complete enlightenment); as Taoists, that the world is governed by a trinity of supreme gods, personal; and, as Confucianists, that the supreme power that rules the world is the impersonal heaven, impersonal though endowed with 
consciousness. Westerners must understand that the Chinese people seldom participate in and practice only one specific religion in one time, though they usually refer to Confucianism as the only main cultural stream of the nation. As the popular religion is very malleable and elastic, and allows all individual interpretations, Budahism, Confucianism, and Taoism do not appear to belong to a different religion from the laity, and so do not lose touch with each other. The personages of the three religions lead deviant kinds of life, however, human relations are its centers of interest. It is an assertion of human existence and effort, and it considers living a harmonious life with one's neighbor as man's first duty. 14

Chinese look upon Confucius as a sage, a teacher, an example of personal cultivation. Even after the introduction of Buddhism from India, the two systems of Confucianism and Buddhism stood on equal footing. A small boy entering into kindergarten would be required by his parents to perform a sort of Buddhist ritual to worship Confucius, in order to be blessed by the greatest teacher in history. In the nineteenth century, when the missionaries from Europe came to China, the Confucian "converts"15 were still allowed to have ancestor worships in a Buddhist and Taoist way. The Catholoc missionaries, headed by Ricci Matteo, accepted this Chinese tradition. Until today, in Hong Kong, Taiwan, the Jesuits and the Catholic Dominicans still allowed the 
tradition to be carried on. It was only the Protestant missionaries, who were unaware of the tradition, who forbade the ancestor worship. ${ }^{16}$ This is a typical tragedy in history, and the main reason for the tragedy was the misunderstanding of the cultural orientations of the Chinese people by the Westerners; ancestor worship was something of the greatest importance to them; anyone who wanted to destroy their tradition would be considered an enemy.

The simplest way for a Westerner to understand Chinese culture is to study Confucius' works. Most of the Chinese people's cultural orientations can be traced back to it. As Wright says,

Confucianism's operating principles might be distilled from the whole corpus of the Classics or from his didactic writings meant for day-to-day guidance in the conduct of life. The Analects of Confucius is both the basic text of the tradi-17

He also says,

.. the authority of the Analects was unchallenged and its lessons were sharply etched on the minds of the young. 18

The young are taught to adhere to approved attitudes and behavior patterns of Confucian philosophy. Some of these orientations are unacceptable to the West, which emphasizes liberty and democracy. They are also unacceptable to the Communist regimes, which emphasize "party dictatorship." But most of the Chinese accept these attitudes and patterns. ${ }^{19}$ 
To summarize, the basic cultural orientations of the Chinese people are as follows:

1. If one wants to be recognized as a gentleman, he has to be submissive to authority. He must honor his parents, obey their orders, and succeed to their roles. No one can criticize or argue with his parents even though the parents are wrong. When a child is young, he is taught to take care of his parents when they are old. An elder brother can take up the role of a parent if the parent is absent. A junior should always listen to a senior. Elders have the authority to judge the right or the wrong. A gentleman is also submissive to the superiors. A teacher is always considered to be a superior. A teacher is equal to a father. Thoughtfully a teacher should always take good care of the student, and the student is a disciple of the teacher. When he becomes successful he should always honor his teacher. So a sense of submissive respect has been built up in the Chinese mind. .

2. Chinese people are faithful to their mores and norms. If anyone does anything which violated the norms he would be considered as a rebel to society. For example, physical marriage is something which only takes place between a man and a woman after the wedding ceremony; if any man and woman have any premarital sexual relations they would not be accepted as a perfect couple. Homosexuality is considered something very evil and dirty in the Chinese 
mind because it is against the norms of nature. When a man does something in darkness it is also considered wicked. When one does anything he has to do it openly and with adjustment to the norms.

3. Chinese people emphasize the primacy of broad moral cultivation over specialized competence. When one is young, he is always taught to learn the broad moral topics in how to be a great man; he is encouraged to follow some perfect ideals and famous figures in history. They are not encouraged to study things in detail. In discussions, usually only guiding principles of life are brought up. This is why Chinese students in the United States have always been in trouble at the time of class seminars and the writing of a thesis. It is very hard to formulate a specific topic. They won't think of such topics as "The Nixon-Chou Peking Communique, May 9,-1972," but rather "The SinoAmerican Relations in Time of Nixon's Reign."

4. Chinese have a preference for nonviolent moral reform in state and society. No matter how corrupt the state is, one should not protest with violence. One can suggest the possible ways of reform in a warm and gentle manner. This is why some of the famous social and political revolutionaries in Chinese history were not accepted by people though they were very successful in their political lives. People thought their violent actions were against the natural law. This is also the reason why there had not 
been many Chinese students in America engaged in violent campus movements, in aggressive, political campaigns, or in angry protest and demonstrations. Nine out of ten Chinese prefer a soft moral reform rather than a violent one.

5. In having a nonviolent moral reform, Chinese believe that this will keep them in a prudent, cautious, middle course. They won't go to the extreme. Going to the extreme is a danger to one's life. So the radicals are considered to be the revolutionaries, rebels, or bandits of society. A gentleman should always keep to his middle course of life. There is no need for one to be special; a well-educated man should not be an outspoken figure, he should remain solemn and calm and common in society. In order to be prudent and cautious, one should not say "more words than he should say" and he should not always say "no" to his acquaintances, especially to his elders, parents, and teachers.

6. Traditional Chinese prefer the spirit of noncompetiveness with each other. Nothing is important enough for them to compete. Competition is not encouraged in family with brothers and sisters. A student in school would not take his classmates as competitors. His concern is not so much in the grades but his own degree of acquiring knowledge. This might be one of the vices of Chinese culture. Some people take it as an excuse to become lazy and nonprogressive. 


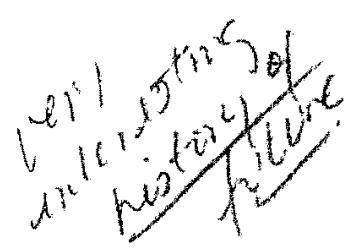

7. Chinese are quite loyal to their nation. They are taught courage and a sense of responsibility to maintain a great tradition. They are made responsible for the history of the future. When the Sino-Japanese War broke out, thousands of overseas Chinese went back to join the Chinese army; when a Chinese student hears something said unjustly about Chinese people and the nation, he.will stand up and argue for them. When they talk, they take up the responsibility of speaking for their country and people.

8. Chinese people. pay much reverence to their five thousand year old history. They are reminded what the past has done to the development of the Chinese culture. They are always reminded of the great deeds and contributions of their ancestors; and they always adore the glory of the ancient emperors. They take the past as a mirror for the future. Anyone who has forgotten their ancestors and history would be looked down on by other people no matter how successful they might be. Grince

9. Chinese are taught to treat others as one would like to be treated. This is because of the belief in acceptance of the reality of both sameness and difference apparent in all people. This is manifested as the golden rule of Chinese behavior. It does not imply that people are all the same but that they are both the same and different. It does not matter which color, race, or culture 
one belongs to, these factors do not hinder the concept of "people of the Four Seas are brothers to each other."

\section{WESTERN CIVILIZATION}

The concept of God has been the most important cultural orientation of the Western people: In his theology of Culture Paul Tillich distinguishes,

- . two ways of approaching God: the way of overcoming estrangement and the way of meeting a stranger. In the first way man discovers himself when he discovers God; he discovers something that is identical with himself although it transcends himself infinitely, something from which he is estranged but from which he never has been and never can be separated. In the second way man meets a stranger when he meets God. The meeting is accidental. Essentially, they do not belong to each other. They may become friends on a tentative and conjectural basis. But there is no certainty about the stranger man has met. He may disappear and only probable statements can be made about his nature.20

From what Tillich has said, there is always an uncertainty in the minds of the Western people. Since God is uncertain, everything is uncertain also. This is why the Westerners are taught to be suspicious of all things around them. It is through their curiosity that a lot of scientific discoveries have been made.

The Western people are taught to prove the existence of their almighty God. As Fromm asserts:

- - the ontological argument that Deus est esse is based on the authority of the Word while the cosmological argument is based on the authority of reason as embodied by the Church. 21 
It is through all the repeated arguments that the Western concept of reason and will have been brought up. All the Western world has centered their concept around reason and will. God to them is a matter of the transfiguration of these two. Modern Western men are taught that God permits them to have the ability to think logically and freely with their own will. Vice versa, they have formed their God in their image. Iudwig Feuerbach startles the modern world by saying :

In religion the Divine has been created by man 22 in his own likeness. God is the image of man.

No matter how the modern Western people take God, they are instructed to believe in Christ.

The Western people are taught to believe in the theory of creation. As Fang explains:

a. The Judaeo-Christian religion set out a creation of the world out of nothing by the almighty personal god, to be argued about by later philosophical theologians ontologically, cosmologically, or teleologically. b. Plato started a theory of creation by way of Demiurge, transporting the absolute values, already subsistent in the transcendental realm, into the crude material domain so as to make it orderly. 23 .

The different kinds of arguments regarding the theories of creation led to the scientific type of researching. The Western people believe that steps in evolution give rise to order of life. Evolution gives rise to a graded system of orders, which affect the mind and the material aspects of the human society. Westerners thus are instructed by a culture built upon reason and will, and they believe in 
materialism. Materialism has been considered as the result of development of technology, and the development of technology is the process of evolution. 24

In Western literature, great poets and distinguished philosophers have praised the individual dignity of man. The concept of individualism causes Western people to be very independent. The idea of dignity of man gives rise to the respect of other people. Every individual has his ideal and goal. They are taught that in order to survive they have to be hard-working and progressive. The result of this is a better living.

In order to have a better living, one has to major in a certain specific field. This is why the Westerners are more practical and empirical than the Easterners. And in order to outdo other competitors in struggling for a better life, the Westerners know very clearly "to fall behind other people means to be eliminated by society" so they have a very strong spirit. of communicating with others through competition.

Western people are educated in a way to have the spirit of adventure and discovery. They believe in "no adventure, no discovery." To them, either they would succeed or fail; there is no middle course in life. So students in university are very self-conscious. They do not depend too much on the instructions of their teachers; instead they want to do their own research and study in order to have new discoveries of their own. 
Western people are not very much interested in highsounding principles and traditional learnings; history to them is not so important as compared to the Easterners; the past has passed already. What they are concerned with most is the present and the future. Sometimes, because they are very eager to fight for a better future, they will become aggressive and courageous.

Because the Western culture emphasizes practical rewards, when a Westerner does anything he would likely judge the matter by a logical analysis. Either he would use the method of positivist reductionism or radical epistemological subjectivism. The former gives a better and more quantitative result in accuracy; the latter would turn down all the existence of "cultural orders of art, world orders of life and minds, morality and religions."25 This is the reason why the Westerners only have the concept of "yes" or "no," "right" or "wrong," "false" or "true." A person brought up in such a society would have little room for negotiation with others.

The learned Max Scheler gives a very good description on the cultural characteristic of the contemporary Western cultural orientations. He says,

It was only in the European and American "community" towards the end of the eighteenth century that an essentially mechanical view had become so gradually diffused among all classes as to constitute a common and "relatively normal" way of looking at things. And this creates an.altogether new spiritual cleavage between man and man, no less between man and nature. 26 
Chapter 3--Notes

${ }^{1} \mathrm{~J}$. Hackin, "Introduction," in Asiatic Mythology, by Paul Louis-Couchoid (New York: Thomas Y. Crowell Company, 1972), p. 29.

${ }^{2}$ Idem, "The Mythology of Buddhism in India," in Asiatic Mythology, by Paul Louis-Couchoid, p. 62 .

3 Ibid., pp. 62-99.

4 The "heart" means "mind" in the Indian and the. Chinese concept.

5 Many of the ideas have been taken from the books: The Buddhist Tradition in India, China and Japan (New York: Vintage Books, 1972); Kenneth W. Morgan, The Path of the Buddha (New York: Ronald Publishing Co., Inc., 1956); Chien Mu, Ten Lectures on Life (人生十論) (Hong Kong: JenSun Publisher, 1948); Arthur F. Wright and Denis Twitchett, Confucian Personalities (Stanford, California: Stanford University Press, 1962).

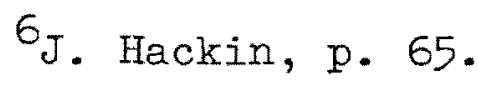

7 Robert T. Oliver, Communication and Culture in Ancient India and China (Syracuse, New York: Syracuse University Press, 1972).

${ }^{8}$ Ake Haglund, "Introduction," in Contact and Conflict (Malaysia: Berlingska Boktrycheriet, Lund, 1972), p. 9.

${ }^{9}$ Sutta Nipata, verse 136. No publishing information. These poems and. sayings are often handed down by word of mouth, generation to generation.

$10_{\text {Tathagataguhya, Sutra, Siksasamuccaya. }}$

Il Aryadeva, "Four-hundred Stanzas."

12 E. A. Burtt, The Teachings of the Compassionate Buddha (New York: Mentor, The New American Library, 1955), p. 55 .

13 Arthur F. Wright and Denis Twitchett, Confucian Personalities (Stanford, California: Stanford University Press, 1962), p. 3.

${ }^{14}$ Carsun Chang, The Development of Neo-Confucian Thought (New York: Bookman Associates, 1957), p. 15. 
${ }^{15}$ This word "convert" is a Western conceptualized term bearing the influence of Christianity.

16 The rejection of ancestor worship by the Protestant missionaries was one of the main causes of the later Taiping Rebellion, 1867, and the Boxer Rebellion, 1889.

17 Wright and Twitchett, p. 8. $\quad{ }^{18}$ Ibid., p. 9.

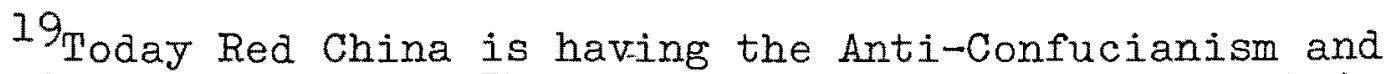
Uphail Ch'in Movement. The primary goal of the movement is to destroy all the basic cultural orientations of the 700 million people, which saddens those who wish to retain traditional cultures.

20 Paul Tillich, Theology of culture, p. 10, cited by Thome H. Fang in "The Alienation of Man in Religion, Philosophy and Philosophical Anthropology," Chinese Culture, I (Taipei, Taiwan: National Chenchi University Press, 1972), p. 10 .

${ }^{2 l_{E}}$. Fromm, Psycho-analysis and Religion (Taipei, Taiwan: Sun-chun Publishers, 1971), pp. 34-37.

${ }^{22}$ Die Philosophie der Zukunft, S. 72 , cited by Karl Barth in an "Introductory Essay" to Iudwig Feuerbach's The Essence of Christianity (New York: Harper and Row Publishers, 1957), p. XII.

23 Thome H. Fang, "The Alienation of Man in Religion, Philosophy and Philosophical Anthropology, "Chinese Culture, I (Taipei, Taiwan: National Chenchi University Press, 1972), p. 33 .

$$
24 \text { Ibid., pp. 16-25. }
$$

25 . Carnap, Philosophy and Logical Syntax (Iondon: Kegan, Paul, Trench, Trubner Publishers, 1935), pp. 88-89. 26 Max Scheler, The Nature of Sympathy (New Haven, Conn.: Yale University Press, 1954), pp. 83-84. 
CHAPTER IV

\section{INDIAN, CHINESE, AND EURO-AMERICAN VALUE SYSTEMS AND THOUGHT PATTERNS: \\ COMPARISON AND CONTRAST}

Before beginning this chapter it is important to make clear the cultural heritage of the writer. He is an overseas Chinese having received his cultural orientation from an Anglo-Chinese cultural society. Although he had hoped to present his ideas in an objective way, he often failed. Criticism from Euro-American readers found many of his assumptions partial and biased from an Asian point of view, just as the Euro-Americans are biased by their point of view. However, this is one of the goals of this thesis: to-let people of different cultures be aware how difficult it is to achieve successful intercultural communication. Writing this thesis was an illustration in itself of the difficulties of dropping one's cultural thought pattern when trying to write for readers of a different orientation.

A second observation is that, although assumptions are made and conclusions are drawn in this chapter, they are not through direct observation and empirical research but through the extended studies in Indian and Chinese as well as EuroAmerican socio-philosophic readings. So many of the 
assumptions are traditional cultural phenomena. This chapter will be devoted to these traditional cultural phenomena taking out major and specific aspects that unnoticeably and automatically affect intercultural communication. All of the chosen traits are common and general in human lives, yet it is because of their commonality and generality that people have ignored them as important influences in intercultural communication on an interpersonal level. This is the reason why the writer takes the risk in writing this broad and "impossible" topic.

The third caution for readers is to be aware that the "truths" in this thesis are those that summarize the ideals of millions of people for almost four thousand years; they have stood the test of time. The ideas presented are not pointing to a specific generation or a particular historic era. It is impossible to draw a definite time limit for the development of a culture.

The fourth point to understand is that despite the advantages of the writer having been culturally oriented in Buddhism, Confucianism, and Christianity, he had a lot of practical difficulties in organizing his ideas and contents in the Western fashion and presenting them in a structured, scientific, logical, and easily understood way. This is another illustration of the difficulty of presenting ideas to a different culture. Also, limited by his ability in 
writing English, he has felt that it is quite a risk for him to express all the ideas freely and thoroughly. Nevertheless, the writer hopes that his extended studies in Indian and Chinese as well as Euro-American cultural orientation will enable him to present this chapter substantially.

Like every student who studies socio-philosophy, the writer is deeply indebted to the scholars who have published the texts and been responsible for the fundamental work of research.

The writer has occasionally found out that some translated reference books from Indian and Chinese languages have been erroneous and misleadingly interpreted by the translators. Some Western translators have already conceptualized their Western points of view into the Eastern books during the processes of translation. So when there was some doubt about the translations, the writer read the original texts by himself, or tried to translate the original texts by himself, if the original texts happened to have been written in Classical Chinese. For Indian, he had to consult some Indian friends for help of further explanations. It was also hard to find references on how cultural orientations and thought patterns affect intercultural communication, though a lot of philosophic books have been written. Another caution for readers is that as Sam Keen says, Any time we line the world up in two columns of concepts and make them march after the names of Greek gods or isms or ologies we are in danger of 
distortion. Typologies are useful tools; they help tease out the logic of a world view, help us see patterns. It is sometimes useful to separate sheep and goats, rationalists and romantics, goods and evils. But if the world is limited to a single either/or we will always have to choose between the devil and the deep. blue sea.... 1

This chapter contrasts some of the basic thought patterns of Indian, Chinese, and Western cultures ${ }^{2}$ relating to the cultural orientations discussed in the previous chapters of this thesis. The thought patterns categorized are: will, activity, desire, progress, attitude toward rhetoric, caste, distinctiveness, change, hero, reason. They were chosen because they fit the criteria mentioned in Chapter 3 of being (1) unnoticeable, (2) as automatic as breathing, (3) common, and (4) general, and because they offered the most apparent contrasts to the author as he experienced a new culture and read the classical literature. In each pattern concrete intercultural communication events in history and literature are used to support the set categorization. It is open to argument that the area of discussion is broad, and the points of discussion may fall into stereotypes and generalizations. The author has attempted to discover through research those factors which are so basic and common in affecting human communication that people have neglected their importance as people have neglected breathing. The author hopes it will remind himself and others of their own cultural traits, and help to give explanations to their communication behaviors 
within their own culture as well as between other cultures. By so doing, a better understanding would be built up, and a better sense of respecting other people's behavior would be experienced. The author does hope his readers, after finishing this thesis, will at least have a heartful breath of their own cultural air, and be reminded no matter how modernized and scientific the contemporary world is, people cannot shake off their cultural cloak in their communication with others.

Will

The Euro-Americans believe the most important attribute of mind is the existence of will. Only those who have a strong and persisting will can be successful. The saying goes, "Where there is a will there is a way." The EuroAmericans idealize willfulness because they have been brought up in a society where people emphasize working out their own ways by their own will. The old Testament is a record of a series of God's works of creation through His own will. The story of Christ's coming is also an act of God's will. The discovery of the New Continent was the result of Christopher Columbus' strong will to find an answer to his scientific curiosity. The landing on the moon by the astronauts is another example of their will. Each achievement adds reinforcement for the Euro-Americans to believe more strongly in will. 
The Indians have a very different point of view toward will. They have the illusion that will is something created by man and the will of man leads him to unceasing lust and desire in the search for material satisfaction and sexual contentment. Only those who avoid the willful state of being can avoid externàl and internal frustrations and disturbances. It is a matter of record that the Indians are the most peace-loving and religious people of the world. They have been much affected by this pattern of thought of their ancestors. For them, to live a life in compassion, serenity, and calmness is more important than to have a strong will which would mean someone did not have a peaceful mind. What need is there to find new lands? What need to search for new scientific theories? If an apple drops to the ground, why not just ignore it or pick it up and eat it? Why should one question why it falls? The stars are to enjoy, not to wonder about.

The Chinese take will as something born to them by nature. Unlike Euro-Americans who idealize willfulness, and Indians who disbelieve in will, Chinese appreciate but are not dedicated to will. They believe a strong will will lead to success and prosperity, but if the will is too strong and uncontrolled it will also lead to quicker and more desperate failure. The Chinese people do not encourage people to have a weak will, but anyone who has a weak will will not be condemned by other people. The Chinese believe a weak will 
will lead to passivity and unfruitful establishments, but it is more elastic and one can last longer in walking through one's lifetime. There is no reason for them to be for or against will. A Chinese has this conflict within himself. It is a matter of fact that he should live life fully and enjoyably, so why should he have strong will to make him work sorely and bitterly? But if he does not have a strong will, he could not have a good and prosperous life. What to do? Should he follow Confucius or Lao-Tzu? The former instructs him to have a permanent will and the latter insists that a strong will would fail one more quickly and easily. It is excellent that man has landed on the moon, but what does this act mean? It is not harmful to become a hippie, but is he constructive to society? All these conflieting ideas would come to the mind of the chinese, and he would never-decide.

The following is an example of how the contrasting thought patterns of the three different peoples can cause communication difficulty. Three students in a sociology class were assigned a group project. One was an American, one Chinese, and one Indian. The project was a field work experience in some slum areas around Portland, Oregon. Motivated by a strong will to do the project beautifully and successfully, the American student put up positive suggestions and steps to do the project. But he later became somewhat disappointed because the Chinese partner 
seldom expressed himself. He just followed the suggestions with no criticism or ideas of his own. He accepted the questions with a slow and tiresome attitude. The Indian student did not show any interest at all. He talked some during their group discussions, but did not satisfy the American student. When the three of them did the field investigation, the American was eager to catch somebody to talk to so he could get more material for the group report. The Chinese was sometimes quite eager, but sometimes not. The Indian was always watching his partners with a smiling and calm face. He was irritating to both. The report was finally written by the American with some help from the Chinese. There was no consensus, just upset feelings. The American was mad because he "had, to do all the work." The Chinese was confused by lack of clear direction, and the Indian felt pressured and withdrew. When asked whether they liked the experience or not, the reply from the American was: "Yes, but I would like to do it again with some other guys!" The Chinese said, "I don't know whether I like it or not. Since I was told to do it, I did it happily." The Indian gave a very negative answer, "I did not want to do it. What's the advantage of exposing other people's poverty. Maybe they like to live in that way." 
Activity

The different attitudes toward will leads to similar differences in attitudes toward activity. For EuroAmericans to live, they have to act. To live without activity is death. If they are free from work, they will try to recreate themselves or to figure out something to occupy their leisure. They think that to live without acting is a shame, no matter how poor or how rich they are. This is related to the strong will to live a better life and to have a better future. The Euro-American culture does not have too much to do with the "mystic" concept of being. Their whole history of cultural development is a record of active achievements, especially in scientific establishments. Aristotelian philosophy and Christianity are very active and outward in comparison to the Eastern philosophers and religions. They have been very much influenced by the ideas of "act." As it is said by Jesus, "ask, and the gift will come, seek, and you shall.find; knock, and the door shall be opened to you." 3 All these words, "ask," "seek," "knock" suggest activity. Under such a cultural orientation, EuroAmericans form a concept of life which emphasizes activity. But Indians are different. They don't think of acts as something affecting their future. They idealize life in Being. Being is living what one is. Because most of them believe in the concept of perpetuality, they take Being as something eternal, the timeless. To them, living and 
acting are temporal, temporary and illusory. Maybe one is living in this world now, but a second later he may pass away silently. The life of this world is so short and unexpected, why bother to act painstakingly? Everything material in this world is like illusive images; a table is not a table forever, the wood will not be wood any more after a long time, and the table would not be a table if the wood does not exist. The Indians have always been taught to live in calmness and quiescence. In order to live in such a state of Being, activity has no great importance. Only in passive moods can the state of calmness and quiescence be maintained. If everything in this world is illusory and temporary, then there is no need to act and to establish. No matter what one has achieved in his lifetime, sooner or later everything will vanish. Activity thus becomes meaningless.

Characteristically, Chinese have convictions on both active living and passive being. They believe both the confucian principle "The way to be is to do" and the Taoist, "The way to do is to be." They are convinced by their traditional thought that whether "to do is to be" or "to be is to do," living and being are accomplishing each other. According to the ideas of Confucius and Lao-Tzu, they are taught to be adaptable to the living environment. They enjoy activities but they are calm when activities slow down. Most pertinent is that they do not search out activity like the EuroAmericans, nor avoid it like the Indians. 
Since the Euro-Americans, the Indians, and the Chinese have different points of view of living and acting, it is interesting to see some concrete examples taken from the three different orientations. A poem written by Liu Tsungyuan in T'ang Dynasty can be used as a good illustration:

A hundred mountains and no bird,

A thousand paths without a footprint,

A little boat, a. bamboo cloak, river-snow. 4

The poet Iiu Tsung-yuan was a Buddhist-affected Confucianist. His poem would probably be viewed in these three ways:

(1) a Euro-American cultured people would think Liu was a passive man. Everything is nonactive. It is monotonous and simple. It is a good way of living for the old people only; (2) an Indian, when reading this poem, would be very much impressed by the poet's live-in-Being style. This is the way he aims his life. He would think it suitable to meditate and to keep emotionally calm. The simple activity of fishing is only a stage leading to further peaceful and undisturbed realms in life; (3) to a Chinese, fishing itself is an activity which can refresh his mind and soul; this can purify his thoughts and spirit. The mountains, the water, the boat are concrete things that lie in front of him. If he is hungry, he can fish for food, and if not, he can take the act of fishing as recreational activity.

People usually have different answers to such a simple and routine question as: "What are you going to do this 
weekend?" A Euro-American would never tell you that he is going to stay at home and sleep. He would probably tell you that he is going to have some outdoor activities, but never just stay indoors and do nothing. An Indian would probably not have any plans for his weekend. The most likely thing for him to do is to stay indoors and read something or meditate for the whole day. A Chinese confirms nothing befere: the weekend. He would usually wait and see what would happen in the morning of the day; he would either go outdoors or he would stay indoors the whole day without doing anything. Some of them would engage in a seven-day work week if they believe that "to be is to do," and some would just relax and do nothing if they believe that "to do is to be." This is the Chinese tradition. So it is not surprising to see a Westerner working all the time and an Indian relax often, or a Chinese become lazy at one-time and become diligent at another time.

It is easy to imagine the misunderstandings which must occur when these actions and inactions are observed by the other cultures.

\section{Desire}

Euro-Americans desire to achieve something in their lifetimes. They approve and encourage desire as the source of future satisfaction. No one should be satisfied by the past or present conditions of life. Satisfaction comes through material possessions and mental capacity. One 
should have the desire to have a better life and his desire will get something for him that would give him a sense of satisfaction and delight.

In order for the Indian to live happily, he has to diminish his desire. He has always been reminded that desire is the root of all evil. It is the source of mental and physical frustration, body and soul torture, and ego and super-ego conflict. Whenever there is desire, there would be no calmness in heart. Why do the Indians suppress desire? According to their cultural and religious teachings, suffering in man's earthly life, sorrows in man's behaviors, and frustrations in man's livings are caused mainly by the self-centered desire. They are taught in order to attach to the ultimate aim of the good--the Being--one has to avoid having desire when he is living in this world. Desire is the greatest block for him to reach the goal-of Nirvana. In the realm of Nirvana there is the state of nothingness.

Chinese people take desire as something very natural, there is no need to suppress desire. But Chinese people do not try to promote desire, because they do believe desire is sometimes the source of evil deeds. They feel that anything natural is good. Desire is natural, so it is good. Vice versa, desire is sometimes evil, but evil is natural. Evil is not accepted as something good to the human world, but since it is natural, people cannot go against it. So let desire take place or not take place; either way. Why do the 
Chinese neither suppress or promote desire? If someone reads Chinese literature he discovers that Chinese depend much on the natural law. Confucius tells people to keep their desire in a right way. In his Analects he says that everyone has the desire to become rich, but if he does not use his good desire to become rich he is not right. 5 If he desires to be rich, he should use his desire in a true and honest way. Lao-Tzu does not encourage people to have desire; in all his teachings to the students he cautiously tells them that desire in man sometimes will lead to evil deeds. This is the main teaching in his Gospel or Morality. Man has to always keep from being tempted by his lusty desire to become evil. So the Chinese people keep both the teachings of Confucius and Lao-Tzu in mind, without letting them conflict with each other.

For a practical example of how these orientations affect communication, here is a short report from the Illustrated Weekly of India published in New Delhi.

There are 11,500 licensed handcart-pullers in this city. [Ahnedabad] There are also many who are not licensed. Their lot is no better than that of beasts of burden. 6

This is the view point of a Christian writer. It shows that in the writer's mind these handcart-pullers should desire to live better than just maintaining their poor status quo. They, under the observance of a Christian-oriented writer, live lives as "beast of burden." So it is unbearable to a 
Western man. But the following gives a very thorough explanation of the situation through an Indian social worker, Mrs. Ila Bhatt:

The sight of barefooted girls and grown-up women pulling heavy loads up steep slopes in the hot sun is truly distressing- But the Khadi-clad, Grandhism, Animsa-saturated Ahmedadis do not see anything degrading in this. They are earning well and do not complain. "In these days of unemployment, there are many worse off:" is their way of looking at it.?

Mrs. Bhatt went on to explain,

They have not come out with any complaint of ill treatment; I agree it is an eyesore, particularly when the women pull handcarts with a baby perched atop. But it is purely an arrangement between husband and wife and any interference is resented. 8

To a "civilized" Westerner, these poor conditions of the women handcart-pullers are an "eyesore," but how about to a Chinese? He would probably accept the job as his fate. But unlike the Indians, he would have a desire to take up other better jobs if he got the chance or if his financial conditions improve. He would not stay in this harsh job for Iife. Similarly, he would not complain if he could not find other better jobs to replace his poor job. It is sure that he would save some money to change jobs in the future.

It is unlikely that such a job' as handcart-puller would be taken up by a Western woman. Westerners would consider it unpleasant and inefficient. They would either complain a lot, find a different job, or find an alternative way to get the job done. Their strong will would push them toward a 
solution acceptable to their desire for comfort and improvement of their life style.

\section{Progress}

Motivated by their strong desire, the Euro-Americans are very progressive. They believe the more progressive one is, the more successful he is. The great establishments and inventions of the Western world are the results of the concepts of progress. There are reasons making the EuroAmericans progressive by character. The first reason lies in the concept that material achievement is progress and progress is success. The second reason lies in the optimistic belief of the people that if one has done his job well, he will not be disappointed. He will progress to a better stage of livelihood. The third reason lies in their independent individualism. If one does not progress by his own efforts, he would not be strong enough to stand for obstacles and difficulties, and if each one contributes something individually to society, society will be better.

The Indians, affected by their suppression of desire, do not take progress as their accepted view of life. They think everything is not subject to the limited time and space of this world, but to an eternal law of the unknown universe. So the Indians idealize every world phenomenom as something leading to the ultimate. Progress is something not eternal. Today it is this, tomorrow it is not anything more. 
The Chinese people prefer progress and new establishments, but they never encourage progress in an agressive way. They are somewhat present-oriented. They do not worry so much about the future; future events are predestined by nature. They believe they did survive over five thousand years because they have never "pushed" the world to progress; this is against the natural law: So they live very. peacefully and will last for a longer time in the future. They face nature and accept it. Why not enjoy the present? To be natural and delighted at the present, the Chinese believe, is something good. It will bring one less worries and frustrations. To live in the present is something very practical and enjoyable. The best way for one to get rid of his troubles is to ignore all the unhappy things happening around him every day and be contented with the present moment. There is no need to quicken the pace of the scientific world; nature itself will progress according to the predestined law of the universe.

Different thought patterns lead to different behaviors and different interpretations of other people's behaviors. Here are two examples illustrating how these different peoples view the concept of progress. The first is related to Western missionaries in Asia, and the second concerns individualism among workers.

When the missionaries from the West came to the East, they bore the idea that they had to preach the gospel to all 
the peoples who had not heard of or believed in Christ. They built churches, walked out to the public, learned their dialects, imitated their behavior and customs, tried to make friends with the local authorities, and then tried to convert as many as possible. They did all this willfully and actively because the missionaries desired to bring salvation to all people and progress to their church: to expand the diocese, to have more converts, to have more influence in the area. Some religions taught that their own salvation depended upon their being able to save the soul of others. When an Indian monk wanted to start his diocese, he probably would build a temple in the mountain. He would not go to preach his Buddhist gospel to the people down the mountain. There was no need to be aggressive in selling his teachings. He only prayed for the conversion of the people. If later the people became interested in his teachings they would come to him voluntarily. The ultimate truth would spread to the believers in a slow and regular way. They believe there is no need to preach the Buddhist gospel in a very progressive way.

The one thing that concerned a Chinese Confucianist or Taoist preacher was to make the people around him acknowledge the natural law. If his followers were convinced of the law, he believed they would live happily and contentedly. So in Asia, Buddhist and Confucianist teachings have scored a large number of believers, and the Christian 
teachings, until today, have not had too great an influence among the general population. This is partly because the Western people do not understand thoroughly the characteristics of the Asians. They tried to sell their religion aggressively citing progress as a benefit, but the concept of progressiveness is not well accepted by the local people.

\section{Attitudes Toward Rhetoric}

In Euro-American literature rhetoric occupies considerable space. From the outpouring of writings on rhetoric, it would appear that the West has been intoxicated with eloquence and the means of attaining it. In the West rhetoric has been considered to be so important that it has had to be explored and delineated separately, as a special field of knowledge about human relations.

From the time of ancient Greece, rhetoric has been as a pattern of manipulative devices or techniques by which a speaker may influence listeners. Affected by the rhetorical teachings of Aristotle, the Euro-American speakers believe that the effectiveness of a speaker is limited by two factors which lie outside his control. The first is that truth and justice are realities; in the long run he cannot deny them, though he may try to obscure them, and in immediate circumstances it should be his duty to uphold them. The second factor is human nature, both his own and that of the audience the speaker will address. Euro-Americans appeal 
both to emotion and reason when they address their audience, recognizing that listeners may also use their own judgment and rationalization. Ethos is very important to the speech because the speaker's character, personality, and confidence also influence the audience. As Oliver says,

Thus, in every circumstance the speaker is confronted by a three-fold task. He must try to accomplish what he himself most. desires, what the facts of the matter prescribe, and what the audience wishes or at least will accept. 9

But in the Eastern literature rhetoric has not been considered so important that it has been explored and delineated separately, as a special field of knowledge. Usually when an elderly speaker is addressing his younger audience he speaks in a parent-to-child fashion. A teacher always instructs his students, a parent always orders his son, a priest always corrects his multitude, so there has not been too much reasoning and justification in listening. A listener is expected to receive "instruction." If you are not an authority figure you do not speak. The speaker does not trouble himself to think about whether the contents of his speech are acceptable to his listeners.

In all rhetorical writings, biography is the set form. In the East, including India and China, rhetoric as a discipline has not been separated from the remainder of human knowledge. Asian rhetoric always has religious-philosophical content. All rhetorical writings (biographies) do not concentrate upon portraying a man's life in all its aspects, as 
an integrated whole. Instead, Indians and Chinese are primarily interested in the record of the people's sanctity and great deeds. All the Eastern biographies are portrayed in conventional set forms. The stereotyped characterization is called topoi (對白). 10 Biography of the type that has arisen in Europe since the Renaissance focuses upon subjects whose character and interaction with their circumstances are of interest. In Europe this interest in the individual per se is evinced in the hero-epic, in the tragedy, e.g., Plutarch. It is perhaps symptomatic of a different attitude toward the individual that among the Chinese neither epicheroic poetry nor tragedy has ever taken strong roots. The whole style of biographies was directed to producing a model--exemplary or minatory, e.g., "The Biography of President Chiang Kai-shek, "Il and "The Biography of Chairman Mao Tze-tung."12 The details of a man's actions; the illustrative episodes characterizing his conduct, the questions and the quotations from his writings, all were selected to produce a consistent and integrated picture. But in the latter eighteenth century, the Western idea of biography, and even more, Western Romantic literature with its almost obsessive emphasis upon the individual personality, began to influence the Indians and the Chinese. With the turn of the century a flood of Western biography, at every level of sophistication, began to be translated, and the Indian and Chinese 
traditions began to transform. ${ }^{13}$ At the same time the authority of the Buddhist and Confucian ideologies, which had provided the universal framework of moral reference for the old biographies, were breaking down in the face of the imported Western ideas, and its old models of conduct and norms of behavior as exemplified in the traditional biographies were rapidly becoming anarchronistic. This is the: result of the "East meets the West"!

As a result of the change both in the rhetorical form and the value system, many of the Asians started to doubt the degree of reliability and truth in the old biographies. They no longer believed everything that had been written or said in the past; they also doubted-whether the hero they had recognized in history was a hero any longer. Examples are the May-Fourth Movement of the Peking University in 1921 and the Uphold-Chin Chi Wang Ti and Anti-Confucius Movement in 1974 in China.

Caste

Democracy is a replacement for anarchy and dictatorship. It means equality and freedom to every individual. Euro-Americans have been much affected by the concepts of individualism--one can do and say anything freely provided he does not violate other people's dignity and freedom. Under this orientation, the caste system, which once existed in the European countries before the Renaissance, does not exist now. In America it is even more advanced in that there 
is almost an absence of privileged classes in the traditional sense. Most of the Euro-Americans believe in the principles of freedom asserted by Montesque and Jefferson. If there is any "caste" existing in the West it is due to wealth and position.

In India the caste system is firmly established.

Oliver says:

It consists of a set of rhetorically effective patterns--customs, folkways, habits, regulations-which shape communicative behavior, including thinking, speaking, listening and responding. The means by which ideas are adjusted to people, people to people, people to ideas are not haphazard. They are regulated by societal needs and established traditions. 14

In India a caste system became established which was as significant rhetorically as it was socially and economically. From earliest times India has been a land of tremendous diversities--of religion, race, language, social customs, politics--yet also a country of indubitable unity. Hinduism placed its stamp indelibly upon the culture and in the personalities of the people. At the heart of Hinduism is caste and all Hindu people are oriented around this. Ancient India's caste system identified every individual inexorably and finally as a member of the caste into which he was born. In the "Code of Manu" the origin of the five Indian castes, or Varnas, is stated as having been created respectively from the mouth, arms, thighs, and feet of Brahma. They are: 
Teachers and Priests

Warriors

Merchants

Farmers

Untouchables

A major effect of caste was to keep united into one culture a people heterogeneous in race, language, occupation, tribal origin, customs, and political organizations.

Caste was successful in India because everyone believed that a given life span is but an insignificant stage in a journey that persists for countless generations, and that what happens during that life span is both a result of prior experiences and a determinant of future status. Thus,

Even the most wretched man with his most degrading occupation remains satisfied with the belief that miseries of his present life are the result of sins in his previous life, and that if he submissively performs his caste duties in this life he will be born in a high caste in the next life. 15

The communication rules of the caste system are divided in two parts: they cover the relations of individuals within a particular caste and relations between members of different castes. In both instances some lattitude of choice exists, but the prescriptions are both detailed and strictly enforced.

As a general principle it might be said that within a caste members are required to treat each other with fairness under difficult circumstances of continuous intimacy; and that individuals of different castes are enjoined to 
maintain strictly a social distance that forbids intimacy and that prescribes clearly the gradations of respect of privilege arising from the respective status of the castes involved. This principle proves to be exceedingly complex, for it incorporates the lifelong and day-by-day minutiae of activities within the family and the community, at work, at play, and in civic and personal affairs.." Caste influence is so pervasive that the individual is never free from it-either in the most impersonal of his civic and vocational duties or in the most intimate acts of his boudoir and toilet. So Wilson says,

It gives the directions for recognition, acceptance, consecration, and the sacramental dedication, and vice versa, of a human being on his appearance in the world. It has for infancy, pupilage, and manhood its ordained methods of sucking, anointing, and smearing; of clothing, dressing and ornamenting; of sitting, rising, and reclining; of moving, visiting and travelling; of speaking, reading, listening and reciting; and of meditating, "singing, working, playing, and fighting. It has its laws for social and religious rights, privileges and occupations; for instructing, training and educating; - - for intercommunion, avoidance and excommunication. 16

In China, though the influence of caste on human communication on the interpersonal level is not as strong as that in India, a mild caste system also affects the communication behavior among the social groups. Influences of caste, community, and family are intertwined. China assigns the role of speaker to a specific person--usually a scholar or an official. He is usually the communicator of an ethnic group. There is an order--the ideally frictionless holistic 
order that had existed in remote antiquity ${ }^{17}$--a hierarchy, a system in which state and society are fused into a seamless whole and every man knows his place and is content because he is present-oriented. A hierarchy of roles was thought and taught to be essential to the ideal order; the vital roles of functionary and perpetuator of the cultural. heritage should be open to those of moral work. The order is such: (sometimes called the Sociopolitical Pyramid)

Mendate of Heaven

Government Officials

Scholar Gentry

Farmers

Workers

Merchants

In a family, the order transforms into the family-code:

Parents

Sons \& Daughters

Servants \& Maids

Every individual is taught to observe the strict and firm moral teachings of Confucius: be submissive to the Sociopolitical Pyramid and the Family-code. There was no such thing as individualism in ancient Chinese communication, but today, under the influence of the Western individualism this phenomenon has changed. There were two characteristic roles a Chinese might choose. One was a relatively stable one: live peacefully and naturally as a common person without having any large ambitions in the future. The second was to 
become a hero in history or a scholar in literature. Virtually the two roles were of the same range, each with its variations defined in the careers of historic figures, and they continued to be the options until the collapse of the imperial order. Individuals commonly made a deliberate choice of the role they were to play, and identified themselves in a deeply personal and emotional sense with the model figure in a manner very foreign to modern Western experience. For example, the chief preoccupation of the Confucian writer, whether he was an official historian or a biographer writing for the family cult, was to set forth the function of the subject in both areas, that of the official and of the family member. These two spheres of activities were viewed as intimately connected, and to them applied a whole system of common moral and ethical attitudes. Within these two broad functions; - a range of conventionalized roles was available to the individual.

The following examples show how the castes of India and the sociopolitical as well as the family-code of China affected intercultural communication in the last two centuries.

The British colonial administrators in India in the reign of Queen Victoria did understand the Indian caste system; they knew clearly and quite correctly that if they wanted to rule India successfully they had to rule her according to the caste tradition. They ruled India for nearly 150 years without many problems, and to a certain 
extent, when speaking in terms of intercultural communication, they were quite successful.

But 100 years later in China, the British failed to see the importance of the influence of the Chinese familycode and the sociopolitical pyramid of the Chinese society. They were not successful when they came to deal with the Manchu rulers, especially with Emperor $K$ 'uang Tse and his powerful mother Empress Dowager (Tz'u-hsi). This was why there were so many international as well as intercultural conflicts from 1842 on. Not until recently did the British discover the character of Tz'u-hsi's hostility. They did not know it originated from the family-code and the sociopolitical pyramid, and this blocked international and intercultural communication between Peking and London. 18

\section{Distinctiveness}

Euro-Americans make everything distinct. They believe that by isolating distinctions, one sees facts and conclusions clearly. Euro-Americans are convinced that reason leads to finding the ideal, not just in forms of things, but also in process. They make distinctions by logical practice and often by the concept of "excluded middle." Between an a and not-a there is assumed to be nothing. Any solutions of the problem must be either an a or not-a , but not both. This analytic method, idealogically, is very realistic. It distinguishes everything by the concept of yes or no. This 
is the orientation of the methodological clarification and mathematic and scientific reasoning.

The Indians believe in indistinctiveness. They are taught that since the ultimate reality is indistinct, then the way of grasping distinctions is wrong and misleading in searching for the eternal truth. So in the method of the Indian Yogins there is the need to eliminate all awareness of distinctions. There are no vivid distinctions between the object and the self. The object is actually only the projection of the self. The method to eliminate all distinctions is to eliminate all negation. They believe in the principle of four-cornered negation. If there is an answer to any problem, it is not like mathematics: it is neither a , not not-a, nor both a and not-a, nor neither a nor not-a. In other words, there is no concrete solution to any problem; there is simply the ultimate reality. As such, nothing is "objective" or "subjective." The subject itself is indistinctive to the object, vice versa also.

Chinese people accept both distinctiveness and indistinctiveness. Distinctiveness is something natural to this world, black is black, it is not white. Indistinctiveness is also something natural, though black is not white, but when all colors are mixed together, everything becomes white, so how could one distinguish white and black? So why not accept whatever appears, and let the argument be taken by 
some sophisticated people? The nature of each thing has both wholeness and parts. An individual is a member of society, and a limb is a part of the individual. So the individual is both a part and a whole in the world; the world exists in a natural cycle. Then why not accept the "bothand" idea? What is being is being, what is life is life, what is nature is nature, there is no need to say yes or no by drawing clarified distinctions. Every matter has its negation, and the position of Man is part of nature. All things on this earth are of nature. They are on the same horizon, so why not accept all the activities that are happening on this earth?

A Euro-American, with his cultural orientation of making everything distinct would sometimes be amazed by the oriental thoughts. This writer's thesis advisor was constantly requesting clarity and proof, unimpressed by what appeared to her as vague philosophy. When a Euro-American does business with an Indian who is oriented in the concept of indistinctiveness, he would be amazed at the Indian way of not accepting or disagreeing with anything. When he does business with a Chinese, he finds it hard to persuade the Chinese to have any new or uncommon projects because the Chinese may not care to find a solution to problems so he would just accept anything as it is. So in terms of intercultural communication, a Euro-American must know that it is not because the Asians are too lazy to find an answer to 
problems, and it is not that Asians are nonscientific, but it is because Asians emphasize more the ultimate value than the practical and immediate functions.

\section{Change}

Euro-Americans prefer change. There would be no progress without change. Change leads to distruction, construction, and establishment. If one wants to have a better and brighter future he has to change his status quo. They also believe there is no construction without distruction during the process of change. If it needs great effort to have some new experience of life, it is worthwhile. All the present establishments of this world are the results of changes in history. It is through all the significant scientific and technological changes of the world that people can enjoy the largest extent of materialism in this twentieth century.

Highlighted by their passive religious orientations, the Indians take change as illusory. It is of no effect in the ultimate reality. Oliver explains very clearly why the Indians do not take change as something leading to social reforms. He says,

India has popularly been considered a land of abstract spiritually, encouraging its impoverished masses to look beyond temporality to some ultimate nirvana instead of demanding social reforms of its wealthy and powerful aristocracy. . .

Whatever India has, it has had for a long time, for among nations, it represents a high degree of stablization. . . 
The reasons are significant. The most preponderant idea animating Indian culture is a belief in the inevitability of both change and continuity.

Perhaps the most dramatic and significant exemplification of this fundamental Indian conviction is the belief in transmigration or reincarnation. To the Indian, birth and death are not the beginning and the end but are incidents in. a continuous cycle of birth and rebirth. A present life has been preceded by many others and will be followed by many more.

Everything that is done or said, neglected or left unsaid, has consequences that stretch across generations. A good life well lived improves the quality of the spirit so that it becomes capable of transmigration. 19

A Chinese considers change as natural. Change is the way it appears. There is no need for man to bring change, when time comes, it changes. As it is something that is beyond the master of human beings, let change come as it is. When it comes, no matter for good or for bad, accept it. Chinese of all ages view the natural human world as an organism made up of multitudinous interconnected parts. When any one of the parts fall from its place or is disrupted in its functioning, the harmony of the whole is impaired. This is the bad side of change. But if there is a force or a sage whose wisdom and power over the minds of man can restore and maintain the desired harmony, universal and unalloyed, it is a good change. 20

The following is an example of how the contrasting thought patterns affect people's behavior. The example is taken from the Indians who have received the teaching of Western Christianity. 
There are about 4-1/2 million Protestants in India. Most of them live in the-northern and eastern regions. Some of our (Indian) finest colleges and hospitals were established during the American and English Protestant missionaries who also played a decisive role in alleviating such evil practices as thuggee, sati, child marriage and the devadasi system. Indian Protestants carry on the tradition by active participation in relief work for people stricken by flood and famine. Their educational institutions continue to be among the best in the. country.21

The above article is written by an Indian Protestant. After being influenced by the West, the Indians in the North and East changed their style of living. They wanted to change the living conditions of the whole area. If an Indian is not a Protestant, he probably would not bother too much to change the surrounding environments. But Indians do not condemn other people who bring changes to their environment. The Protestants condemn some of the Indian things as "evil," and they are proud of the result of their changes. A Chinese possibly would be quite thankful for the Protestants who have built hospitals, schools, and other construction for them, but he could not stand any condemnation from the Protestants because human beings are not qualified to condemn anything natural.

The other example took place three years ago in the Department of Foreign Languages and Literature of National Taiwan University. It shows an American professor (also a Jesuit priest) who takes on the Chinese thought patterns after he has been teaching in Chinese universities for 
45 years. Dr. O'Hara is a very well known and respected professor in the department. He teaches Sociology. There are many young professors in the department. They were his students several years ago. In 1971 a young Chinese professor, after teaching several years in the States, returned to teach in his mother school. All his mind had been filled with American thoughts. He was dissatisfied at everything he saw in the department. He then pleaded to bring changes to the department. So arguments were heard among teachers and students. After a while, Dr. O'Hara, in one of the very casual occasions, stood in front of a group of teachers and students. In Chinese, he said: "I have seen too many changes in China in the past 45 years. That is enough for me. I take this country as my second mother country. I don't see that there is any need to change our Chinese tradition. Why not let everything change in its own natural law?"

One who has visited Hiroshima must be very much impressed by all the neat and beautiful design of the city. The whole city is an example of change, which was brought by an atomic bomb. Here three different points of view can be shown: (1) to a Euro-American, even though they regret that the bomb brought greatest damage to the people and the city-it destroyed everything:--it is through destruction that new things are established; (2) to an Indian, it is a brutal act of anti-compassion, and maybe someday in the long future, 
Hiroshima would be an illusory image in the infinite universe; (3) to a Chinese, the change brought to the city is a predestined fate of the Japanese; it is a natural result.of violating the law of nature.

\section{Heroes}

Heroes in the minds of the East and the West are different.. The West calls a man who contributed to society a great man. A great man should be a producer. He should be a master in skill, intelligence, and efficiency. They do not pay too much attention to the moral aspects of his personal life. If one is a drunkard or has a poor background, he still can be a great man provided he can contribute something great to his community. So the Western people take a hero by judging how much he has. done for them. In the Western minds, people like Newton, Edison, Einstein, Madame Curie are the great men and women of world history. They are the best and the greatest producers of works. To traditional Euro-Americans, however, a great man should be one who is purely intellectual; as Plato says in his Republic:

- the process of emancipation is a purely intellectual one, and that it can be accomplished only

by those endowed with all philosophic gifts. 22

The Indians think a great man is a yogin--a purified human creature with all the highest virtue. He should be a man of quiescence while alive. Even though one has done a lot of good things for the society, if he does not have a 
very purified Great Buddhist-like life style, he would not be accepted as a sage or a hero. His greatness is not only in his material achievements but in his moral-religious devotions. To an Indian, Gandhi is great, the Great Buddha is great, because they are men of quiescence while alive. Burtt gives a clear idea of how the Indians take someone as their hero; he says,.

The sages presented in writings as Vedas, Rig Vida, are struggling to work out a mystical philosophy of the universe and of human nature, with profound implications touching the way that man must follow to find salvation. Such an orientation constitutes a minor historical strand in several great religions, e.g., Christianity, Islam, and Confucianism. In Taoism and Indian religions it is the primary and basic strand, determining the role and meaning of everything in the experience of their adherents and in their theological interpretations. . . One's salvation consists in leaving behind the separate, fearful, self-centered individual that in his finitude he now finds himself to be, and becoming one with the universal and absolute reality--leaving behind the realm of unstable, transitory, and illusory, and becoming identified with the ultimate and eternal ground of all that exists. The passion of the Indian saint is the passion of the fragment for the whole--the longing to throw off the hampering limitations of finite existence and to achieve union of the infinite.23

As to the problem of life, Burtt continues,

- . for this way of thinking, is rooted in the here and now of our daily existence, but the envisioned solution reveals an unquenchable audacity. There is a sense of limitless possibilities of man, in comparison with which everything that he has already experienced before he has already become poignantly aware of them must be pronounced illusory rather than real, darkness rather than life. The task of man is to leave behind the cramping world of his present acquaintance, leave behind his limited self and all that belongs with it, and become one with transcendent reality--with the divine source of all that is great and good and true.24 
Chinese appreciate a man who contributes to love and peace without violating nature; he should be rich in enjoyment of life and rich in sacrifice to his nation. He should also be a man of traditional wisdom and virtues. To a Chinese, Wen Tien-sheung, Yueh-fei, and Dr. Sun Yat-san are the great men.

In his Confucian Perisonalities, Wrïght says,

A man became a sage only through long study and self-discipline which developed humanness or love (jen) and gave him an almost mystical empathy for his fellow men and an acute sensitivity to all the delicately balanced forces at work in the universe, govern the state and pacify the world.25

This is the typical way that the Chinese choose a hero. He should contain love to all the universe. He should be of great self-discipline and humanness. There eventually develops upon a hero the awesome duty of assuring harmony to the world. This is the formed basic qualification of a Chinese hero: he should be steeped in the classics and his-. tory, have stern family discipline, always have introspection, and be of vast responsibility to the human society.

No matter which culture one belongs to, the qualification of a hero can be summarized as the following:

(1) Right understanding, (2) Right purpose, (3) Right speech, (4) Right conduct, (5) Right vocation, (6) Right effort, (7) Right alertness, and (8) Right concentration. But "the problem is that the 'right' way is judged differently by each cultural group. "26 
Reason

Euro-Americans emphasize reason as a way to determine justice and righteousness. Much of their reasoning is polar reasoning. In Phaedo, Socrates says,

Are not all things which have opposites generated out of their opposites? I mean such things as good and evil, just and unjust--and there are innumerable other opposites which are generated out of opposites. And I want to show that in all opposites there is of necessity a similar alteration.27

Westerners judge whether what they want to do is right or not right, just or not just, good or not good. So as

Descartes says,

And I always had an excessive desire to learn to distinguish the true from the false, in order to see clearly in my actions and to walk with confidence in this life.28

What makes the Euro-Americans able to distinguish all these two-pole concepts is their ability to reason. One of the most distinctive characteristics of Western man is his reliance upon reasoning as a determining factor in his life. Euro-Americans idealize reason. They believe rational thought is the method of achieving understanding. Doing anything without using the capability of reasoning is dangerous; reason shows him the probability of further achievement and success. Descartes's four precepts of reasoning is a good example of Western ways of thinking:

1. Accept nothing as true unless it is presented to the mind so clearly and distinctly that it cannot be doubted.

2. Divide each problem into as many parts as possible, in order to reach the most adequate solution. 
3. Proceed in gradual order from the simplest and most easily understood objects to knowledge of the most complex.

4. Make complete and comprehensive surveys and checks to ensure that nothing has been omitted. 29

So reason involves both a process and a capacity. Bahm says,

As a capacity, reason is our capacity to understand. As a process, reasoning is a method for achieving understanding. If we understand the nature of something, then we can predict how it will behave and so avoid evils which might result or possibly use it for our benefit. Faith in our capacity to understand presupposes that the nature of things is understandable, and that what is understood is rational also. To be rational is to involve ratios or relationships between things. So a mind can. reason about things provided both mind and things are rational and involve similar relations. 30

An Indian would not take the two-pole concept and does not apply the analytic method. The thing itself is an illusion and nothing has been confirmed about the thing itself when looking at the ultimate Being. There is no need to say right or wrong, .just or unjust, good or evil. Man's capability does not provide him with the power to discover the unquenchable and mystic truth of the universe. Reasoning will not provide him with the right track of living and thinking. If he wants to attach to the perpetual eternal he has to discover it through intuition--sudden understanding of the thing. Fung says,

Indians in the main have chosen the organismic approach to their objects of study, with a view to gaining a comprehensive understanding of God, man and the world by way of synoptic intuition, presupposing exhaustive analysis but transcending its Iimitations. 31

Why the Indians idealize intuition? According to Bahm, 
Intuition grasps the unity of a whole. It does so directly. That is, there is nothing between an intuiting awareness and what is intuited. Reason, on the other hand, when it infers, proceeds from data or premises to conclusions, often passing through intermediate steps or stages. Whereas inferences may be mistaken, in intuition, or direct apprehension, nothing intervenes to make mistake possible. Hence, intuition can provide certainty because what is intuited is grasped all at once as a whole. When we intuit something, we do not take it apart and then try to put it back together as a whole again. 32 .

This is why Indians do not emphasize reasoning; instead they idealize intuition. There is no need to reason. Affected by their cultural and religious incentives, they believe if one can grasp the unity of a whole, he will be provided certainty and comprehension. Maybe just in a moment an idiot would turn to be a sage if he, in that special moment, has grasped the ultimate truth of the thing.

Chinese also talk about reason and intuition. They are oriented to believe that reason-provides them the way to do something or solve problems regularly and fruitfully, and intuition helps them to have a sudden understanding of the thing. Both reason and intuition are natural things of the mind. Chinese call nature the "Universal Tao." Each Tao is a natural whole with its own parts and its own natural way of proceeding. There is no need to accelerate the natural proceeding. So Chinese accept comprehensive reason. It takes a great effort for the writer himself, a Chinese, to explain why the Chinese accepts both reason and intuition because to do so requires reasoning--a Western trait. Perhaps 
the main reason should be traced to their cultural orientation: they are again affected both by Indian Buddhism and Confucianism. Ch'eng I asserts that "Human nature is reason."33 In occidental philosophy, Ch'eng Ho.describes the two types of reasoning: inductive and deductive.

There are the two schools of rationalism and empiricism. The empiricist holds that knowledge comes from sensations or impressions, while the. relationalists argue that the idea of law does not appear in the data which are bindable by senses. There are forms of thought, in other words, among which is the idea of law, underlying our human judgments. Ch'eng I's statement

"Human nature is reason" means no other than the rationalist doctrine that forms of thought exist a priori in the mind. 34

Ch'eng Ho is one of the most famous scholars in Chinese

history who speaks for reason. He says,

Reason . . to build a system which would contain a cosmology to account for the creation of the universe, an ethics treating mankind as a unity and affirming the value of human effort, and an epistemology to determine the--basis of knowledge of what is and what ought to be ... This new philosophy became known as "the science of reason" or the science of "human nature," because "reason is the common basis of knowledge, and the universe of natural or ethical knowledge are found only by reason in human nature." 35

Like the Renaissance in Europe, the Chinese concept of reason was widespread in the Neo-Confucianism Era; but unluckily, while the European Renaissance produced science, industry, technology, democracy, and economic life in the modern world, Chinese concept of reason failed to achieve any of these things because many of them were Buddhists, affected by the more retreating "intuition." There are 
some similarities in the concepts of reason used by China and France; Ch'eng Ho says "T'ien-ri,"36 Descartes says "Cogito, ergo sum!"37 Both means reason.

The Chinese sage Mencius discusses the universality of the concept of reason:

The principles of reason and the determination of righteousness: what we conceive is the common nature in accordance with which the particulars or individual things are fashioned are rendered intelligible. 38

From what Mencius says, one can perceive that he also speaks of common approval of reason approval by (1) the principles of reason, i.e., in the Western terminology by the principles of theoretical knowledge (logic, epistemology, principles of sciences etc.), and (2) the principles of righteousness, i.e., in the Western sense by the principles of ethics. In Chinese thought these two areas of inquiring are brought so close together that the principles of knowledge are often obscured.

Carsun Chang speaks of the Chinese and Western reasoning.

One of the very important differences is obvious at the outset (East and the West): the confucianists and their spirited offspring take the realm of human relations and the ethics as their principal data, whereas for most Western thinkers in the modern period the world of nature and the quest for knowledge have been the center of their chief interest.

The Chinese Confucianists seldom occupied themselves with the problems of knowledge and methodology, while the Europeans, before they dealt with the substance, first prepared the ground by elaborating critically the technique of clear and connected thinking. 
But the objective of Western and Eastern philosophy is the same. Both seek eternal truth, whether in ethics or in theoretical knowledge-a truth which is impossible to find in the senses, but lies in the forms of thought or of mind. 39

Porter says "the form of reasoning prevalent in a society

is another aspect of culture that influences social perception." 40 He quotes Pribtam's suggestion:

Mutual understanding and peaceful relations among the peoples of the earth have been impeded not only by the multiplicity of languages but to an even greater degree by differences in patterns of thought--that is, by differences in the methods adopted for defining the sources of knowledge, and for organizing coherent thinking . . . the most striking differences among philosophical doctrines are attributable to deepseated divergencies in the methods of forming fundamental concepts and of defining the functions of Reason--that is, the cognitive power of the human mind and the extent and validity of that power. 41

Porter also says,

The extent of variance that may be found between cultural patterns of reasoning may be found by contrasting Western Aristotelian and Oriental Taoist modes of reasoning. Tao teaches the wisdom of being foolish, the success of failure, the strength of weakness, and the futility of contending for power-all of which might be seen as irrational by the traditional mind. 42

Because of these differences in thinking patterns toward reason, sometimes it is very hard for a Western man to read the thought of an Indian or a Chinese. It is easier to understand the Westerners due to their rationality. For example, when a United States teacher assigns problems for a group of international students to solve, it is not easy to know whether the Indian or Chinese students understand what is expected, particularly the Indians. They 
still use their own intuition. Maybe excellent for them, but certainly it is not a good means to promote mutual understanding unless it can be shared. Here is another brief example to show the differences of use of reason in the three main cultures. The following is a quote from Time magazine:

Watergate Bargains: Were they necessary? Since the original Watergate break-in trial, only one defendant, Dwight Chapin, has been prosecuted all the way to guilty verdict (he was convicted of perjury). Mieanwhile, one by one, Frederick LaRue, Jeb Magruder, Donald Segretti, John Dean, Egil Krogh, Herbert Porter, Herbert Kalmbach, Richard Kleindienst and Charles Colson have all made bargains with the special prosecutor's office and pleaded guilty to reduce offenses. If nothing else, their pleas have raised doubts among civil libertarians and law-and-order hard-liners: Were the deals necessary? 43

In the minds of the Euro-Americans, they would possibly first judge whether the act of Watergate itself was right or wrong. They would use reasoning to decide whether the act was justified and whether the country should stand for this law violation. They, would also question the wisdom of allowing negotiation for lighter sentences by pleading guilty, as shown by the article. A Chinese would possibly think the Watergate story is overemphasized. They would direct their reasoning to the "face" and "consequences" of all the bargains. They would accept the idea that all people committing perjury should be punished, but the bargains which admitted guilt are not necessary. A man should not display his wrong doing. To an Indian, the idea is 
simple: this case is a kind of political illusory created by dirty and nasty politicians; the bargains are part of a "game" and nothing to take seriously.

Here is another small example:

When a group of international students participate in a basketball game, they would likely have different attitudes. The Euro-Americans must. try to reason out a method.. to win the game; how to shoot the basket more accurately, how to have all the theories of physics and biology apply to the exercise, the reason for errors, etc. They emphasize how to become a good player. A Chinese would sqmetimes think the game as the Euro-Americans, but he would probably never bother to think about any biology or physics in the field. He would play by intuition and instinct.

In summary, Wang Yang-ming, one of the greatest scholars of contemporary Chinese philosophy says:

- the mind and $\mathrm{Li}$ (reason) are the same thing. External objects are not really independent of the mind. The mind embraces all $\mathrm{Li}$, reason or law. In order to discover $\mathrm{Ii}$, one needs to return to his own mind, which is originally good and clear. Not only is the knowledge of the good inborn, but practising the good is also native, so that knowledge and conduct are identical. 44 '

This quote emphasizes the intuitive-type reasoning of the Chinese, close to the Indian thought pattern, but very different from the laborious empirical or highly rational approach of the..West. 
Chapter 4--Notes

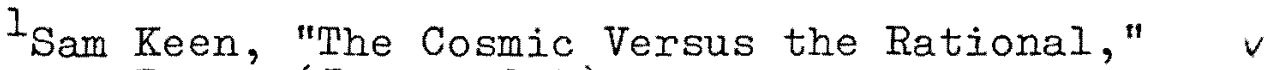
Psychology Today (July, 1974).

2 "Indian" includes Buddhism and Hindu'ism. "Chinese" includes Korean. "European," which has Judaism, Christianity, and Islam influences, extends wherever these ideals have spread, obviously to North and South America.

${ }^{3}$ Luke II, 9-10.

${ }^{4}$ Liu Tsung-yuan, "River-Snow," in Three Hundred Poems of the T'ang Dynasty; trans. Witter Bynner (Taipei, Taiwan: Wun-sing Publisher, 1965), p. 97.

${ }^{5}$ Confucius, Analects, Chap. IV.

${ }^{6}$ Ila Bhatt, The Illustrated Weekly of India (New Delhi) 24 December 1972, p. 37.

$$
7 \text { Ibid., p. } 21 \text {. } 8 \text { Ibid., p. } 8 .
$$

$9_{\text {Robert T. Oliver, "Introduction," in Communication }}$ and Culture in Ancient India and China (Syracuse, New York: Syracuse University Press, 1972).

$10_{\text {Topoi ( }}$ 䍌 ) is a form of writing biographies in Asia. It directs toward giving a "mystic" description of the hero.

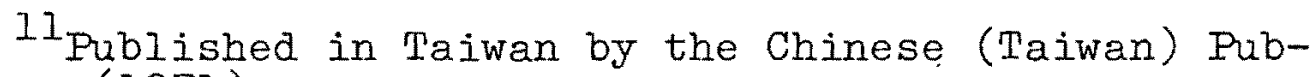
lishers (1971).

${ }^{12}$ Published in Red China by the Chinese People's. Publishers (1971).

13 Oliver, "Biography as Rhetoric," in Communication and Culture in Ancient India and China.

14 Idem, "Caste as Rhetoric in Being," pp. 31-36.

15 Nrioendra Kumar Dutt, Origin and Growth of Caste in India, 2 vols. (London: Kegan Paul, Trench, Trubner and Co., 1931), p. 32 .

${ }^{16} \mathrm{John}$ W. Wilson, Indian Caste, 2 vols. ed. P. Peterson, vol. I (1877), p. 13. No publisher indicated. 
17 Arthur F. Wright and Denis Twitchett, Confucian Personalities (Stanford, California: Stanford University Press, 1962), p. 6.

${ }^{18} \mathrm{Li}$ Chien-nung, The Political History of China, 1840-1928, trans, and ed. Ssu-yu Teng and Jeremy Ingalis (Stanford, California: Stanford University Press, 1956), p. 99.

1901 iver, pp. 12-14.

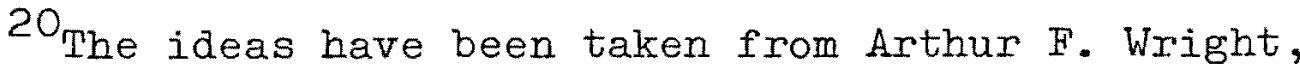
Confucianism in Action (Stanford, California: 'Stanford University Press, 1964), pp. 3-6.

21 Qurratulain Hyder, "The Christian Priest," The Illustrated Weekly of India (New Delhi), 24 December 1972.

22 Plato Republic, Book VII, "Cave."

23 E. A. Burtt, The Teachings of the Compassionate Buddha (New York: Mentor, The New American Library, 1955), p. 16.

24 Ibid., p. 17. 25 Wright and Twitchett, p. 6.

26 Said by Professor LaRay Barna, Portland State University, 1974. p. 149.

27Plato The Dialogue of Plato, vol. 3, Philebus,

${ }^{28}$ Descartes, On Rightly Conducting the Reason, p. 4lb, cited by Mortimer J. Adler and Seymour Cain in Philosophy (Chicago: Fincyclopaedia Britannica, 1963), p. 157.

29 Ibid., p. 160.

30 Archi J. Bahm, "Eastern and Western Ideals: A Comparison," University of New Mexico, 1973, p. 18.

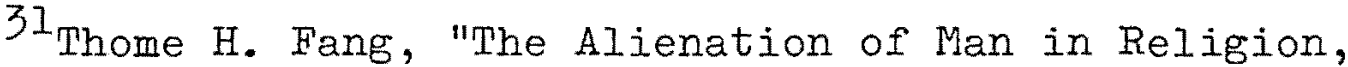
Philosophy, and Philosophical Anthropology, " Chinese Culture, I (Taipei, Taiwan: National Chenchi University Press, 1972), p. 25.

$32 \mathrm{Bahm}, \mathrm{p} .19$.

33 Sung-Yuan Hsueh-An (祬舅案), The Scholarly Records of Sung and Yuan Dynasties, Book 30, "Ch'eng I" (Taipei, Taiwan: Shan-wu Publishers, 1970). 
${ }^{34} \mathrm{Iu}$ Gee, Chinese History (Hong Kong: Iing Kee Book Store, 1957), p. 90.

35 Ibid.

36 Sung-Yuan Hsueh-An, Book 30, "Ch'eng I," "Reason."

37 The Dialogue of Plato, vol. I, Phaedo, cited by Descartes (reprint, Taipei, Taiwan: Wun-sing Printing Co., 1953).

38 Mencius, Meng-Tzu, Book 6, part I. Chap. 7 (Taipei, Taiwan: Shan-wu Publisher, 1953).

39 Carsun Chang, Development of Neo-Confucian Thought (New York: Bookman Associates, 1957), pp. 27-33.

$40_{\text {Richard E. Porter, "Introduction," in Intercultural }}$ Communication: A Reader, eds.: Larry A. Samovar and Richard E. Porter (Belmont, California; Wadsworth Publishing Co., Inc., 1972), p. 11 .

$$
{ }^{41} \text { Ibid. } \quad 42_{\text {Ibid. }}
$$

43 Time, 24 June 1974, p. 64.

${ }^{44}$ Wing-Tsit Chan, Religious Trends in Modern China

(New York: Columbia University Press, 1953), p. 31 : 


\section{CHAPTER V}

\section{APPLICATIONS}

In order to support what has been said about thought patterns and to illustrate more how these thought patterns affect communication behaviors, the following events are taken from the current reports from different countries:

\section{Event One}

In McCrea Hazlett's article, "What About Indo-American Relations?" he explains very clearly why the communication behaviors of the two nations sometimes block out understanding. He writes,

Americans and Indians share common democratic ideals but their governments have failed to estabIish a permanent friendship that will stand the strains of political differences.

Lincoln and Gandhiji, Roosevelt and Nehru, spoke the same language of freedom and set the same cherished goals for their peoples....

But Indo-American relations have never been at a lower ebb than they are today. It is essential for both countries to examine objectively the causes, and remove the irritants

In the sweep of America's development, the impact of Indian thought is more important than those early trade relations. The familiar story bears repeating. One of the main strands in the complex web of American character is a strong idealism. Americans believe in ideals and believe in pursuing them practically.

This idealism found its happiest and earliest expression in the middle of the nineteenth century in Concord, Massachusetts, among a group of transcendentalist thinkers and writers. These men 
rejected the prevailing forms of Protestant Christianity and wrote and thought about the world soul and other topics not strange to Indian philosophers. Ralph Waldo Fmerson was the most distinguished member of this group. He was an avid reader of Indian philosophy. The quickest way to see this relationship is to read his short poem, "Brahma."

The second most important transcendentalist was Henry David Thoreau, whose reputation has so grown with succeeding generations that he is today more widely read than Emerson himself. Thoreau's very famous book, Walden, was dedicated to persuading unhappy men to give up their attachment to possessions in order to free themselves. He was primarily a seeker, not a political activist. However, an incidental political act of his had important consequences for India. He once went to jail for nonpayment of taxes because, he said, he refused to support a government which supported slavery. His "Civil Disobedience" strongly influenced Gandhi, who wrote that it "seemed to be so convincing and trueful that I felt the need of knowing more of Thoreau." Gandhi adopted civil disobedience as a key to the resistance movement. . . These contacts between India and America, though very important, were "idea to idea" rather than "people to people." I

This writing was an example of very successful intercultural communication, not only that an Indian sage understood the nature of an American transcendentalist's thoughts, but he had made use of it to achieve something great to his nation; and vice versa, the American transcendentalist also. It was because they had more or less the same thought patterns, in a rebellious sense--negative and nonviolent protest. If both Gandhi and Hawthorne did not have such a kind of attitude, they they would not have acted in such a way. 
Event Two

Following are three articles showing the differences of attitudes toward hero worshipping between the East and the West.

After the Paris Agreement of January, 1973, the South Vietnamese threw themselves enthusiastically into replaying the history of 30 years ago. The brief, ugly decade of American involvement here was thrown off as though it had never been, "and 'so' surprised were the Vietnamese by the sudden vacuum of authority that they immediately looked to the past to fill it. Overnight they rehabilitated the reputation of the murdered ex-President Diem and formed committees to urge the return of Bao-Dai, Vietnam's last emperor, now living in exile in France. They chose to forget that President Diem ran a police state in which people lived in terror. 2

Ten years ago, on November 22, 1963, President Kennedy was assassinated in Dallas. Many see this date as the moment when American society lost its way. But Americans are quick to pull down their heroes, and they have recently been more critical of Kennedy's presidency than they were at the time of his death. . .

He had considerable faith in human reason dispassionately applied, much less-faith perhaps in human nature. He thus had a premonition of a certain fragility in the American political and social order--a premonition that no doubt fueled his determination to do things to hold that order together while there was still time. And, indeed, after his death the national policy began, it would seem, to fall apart--first the insurgencies of the Johnson years, the uprising among the young, the Woman's liberationists, the blacks, the Indians; then the corruptions of the Nixon years, the lawless White House staff, the irresponsible or complicit president, the crooked vice-President, the pervading indifferences to the laws and the Constitution.

How much did Kennedy himself contribute to the time of troubles that followed his death? Americans have a habit, not entirely bad, of pulling down their heroes rather soon after. they have passed from the scene. Within my own lifetime this has happened, for a reason, to Theodore Roosevelt, to Woodrow Wilson, to Franklin Roosevelt. It is happening 
these days to Kennedy. He is portrayed as a reckless agitator at home, a rigid and embattled cold warrior abroad, a President seductive in style but empty of substance. "Every hero," wrote Fmerson, "becomes a bore at last." Eventually history strikes a balance. 3

For the rest, he [Nehru] remained a man of rare sensitivity and compassion. A handsome man who cared much for beauty, elegance and excellence. A man who would not stoop to tricks which are every politician's stock-in-trade. Far from corrupting him, absolute power did not spoil Nehru in the least. There was absolutely nothing crude or crooked about him. Of how many men, let alone men of power, can this be said? The bad things that Nehru did or allowed to happen must not be lost sight of by any means. But the much greater good that he undoubtedly did should not be interred with his bones. 4

The individual incidents are important for showing the impact of styles of thinking and suggesting how an impasse in this area is interpreted and usually projected to the social and political human interaction. It shows that EuroAmericans do respect their heroes only when they are still alive and can contribute to the present world; whereas the Asians respect their heroes only when they have passed away. In terms of intercultural communication, if an American is so naive (the author knows this is a biased word, but he is naive also and cannot think out another word to replace it!) to criticize the passed away heroes of the Asians, he would not be welcomed because the Asians respect their ancestors very much and believe that no one should criticize them, no matter for good or bad. Any Euro-Americans committing this mistake would not be excused easily. 
Event Three

Here is an article quoted from The Illustrated Weekly of India showing the concepts of the Christian missionaries in India:

There are about 4-I/2 million Protestants in India. Most of them live in the northern and eastern regions. Some of our finest colleges and hospitals were established during the American and English Protestant missionaries who also played a decisive role in alleviation of such evil practices as thugee, sati, child marriage and the devadasi system. Indian Protestants carry on the tradition by active participation in relief work for people stricken by flood or famine. Their educational institutions continue to be among the best in the country. . .

Where I come from, the image of the educated Christian has always been that of the nurse, the teacher, the doctor. Nevertheless, there was almost no Christian middle class. But the poorest of Christian families were models of orderliness, courtesy and piety.

The caste pattern was fairly obvious. Sons and daughters of brahmin and other high-caste became teachers, doctors or social workers. And although many converts from the "untouchable" castes also came up in life, a faint stigma continued to attach to them.

The Christians were at one time criticized for being the by-products of British Colonialism. . .

From the very outset the missionaries faced the problem of Caste, as brahmin Converts refused to mix with those who were not twice-born. The multiplicity of languages was another problem for the missionaries. But the most difficult of all tasks was to persuade the natives that Christianity was philosophically and ethically superior to indigenous religions.

There came a time when many White Young men and women were fired with the zeal to go out East--to Africa, China and India--to save the soul of the heathen. Up to the middle of the 19th century a number of Englishmen labored under the belief that, in due course, Indians would see the light of reason and accept Christianity.

White missionaries started with many advantages: They were better educated, conversant with the scientific discoveries of the times and well endowed. 
They were fired with enthusiasm and energy characteristic of young nations on the rise. And they genuinely believed that God had commanded them to "civilize" the lesser breeds without the law.5

The Euro-American missionaries, advisors, consultants in Asia are sometimes deprived of the many familiar guideposts of their own cultures which allow them to act, to speak, to write without deep thinking, or without much awareness of their culturai orientations. The result is unsuccessful intercultural communication. From the example " given above, readers can see how biased and arrogant the Christian writer is, especially when he uses the terms as "evil practices," Indians could not accept them." To the writer, anything Indian is inferior to that of the West, so that all Indians should be "civilized" by them.

During the process of intercultural communication when the Euro-American is in the Eastern world, each speech or act may require planning and decision; otherwise he may not know that he has irritated technically and culturally the Asians, and thus blocked intercultural understanding. The same is true with the Asians.

\section{Event Four}

The Far Eastern Economic Review in January 1972 published an article discussing the future change for Taiwan showing the different points of view from the East and the West. 
What future change. for Taiwan?

The first casualty of the Kissinger trip to Peking has been the Nationalist govenrment in Taiwan. The staunch U.S. ally for the last 20 years has been disgraced by its eviction from the U.N. with, it is believed in international levels, the traitor consent of the American government. What does this imply for the future of Chiang Kai-shek's regime and the diplomatic status of the island that he rules? Basically there are three options being discussed in the world press: a plebiscite leading to an independent state of Taiwan and the ousting of the Nationalists (Le Soir), a return of Taiwan to the administration of the mainland ( $\mathrm{Ta}$ Kung $\mathrm{PaO}$ ), or the retention of power by Chiang regime for the infinite future, but outside the U.N. 6

From this example, with the points of view from the East and the West, one can see how different it.is to individual nations. How about to the Taiwanese themselves? If one understands the cultural orientations of them, he ought not be surprised to hear such a comment: "That is fate. Let's accept it and don't worry too much about the future changes." 


\section{CHAPTER VI}

\section{SUMMARY}

We need to show that we're not just skull-diggers and headhunters; one of our main tasks is to make "foreigners" comprehensive. Modern communication has reduced the size of the world to such an extent that it's no good any more thinking of humanity as consisting of "ourselves" and "those bloody foreigners" or "those blacks! those Indians!" We have to learn to communicate with them. And to do this we have to learn to understand. the nature of foreignness. This is the very essence of anthropology-how people feel themselves to be different, and what reactions of dominance and aggression, love and hate, cooperation and hostility flow from the feelings of difference. 1

The above was said by the most famous contemporary British

Royal anthropologist, Mr. Anthony Grey. The writer used these ideas and extended them in the previous chapters of this thesis. What has been written has been intended to make "foreignness" comprehensive--so that the Euro-Americans could come closer to understanding the Indians and the Chinese, and vice versa.

The great modern European sage Albert Schweitzer said:

We know very little about any thought except our own, especially about the Indian thought. The reason why it is so difficult to become familiar with this is that Indian thought in its nature is so entirely different from our own because of the great part which the idea of what is called world and life negation plays in it. Whereas our modern European world-view (Weltanschuung), like that of 
${ }^{I}$ Sam Keen, "The Cosmic Versus the Rational," $v$ Psychology Today (July, 1974).

2 "Indian" includes Buddhism and Hinduism. "Chinese" includes Korean. "European," which has Judaism, Christianity, and Islam influences, extends wherever these ideals have spread, obviously to North and South America.

${ }^{3}$ Iuke II, 9-10.

${ }^{4}$ Iiu Tsung-yuan, "River-Snow," in Three Hundred Poems of the T'ang Dynasty; trans. Witter Bynner (Taipei, Taiwan: Wun-sing Publisher, 1965), p. 97.

5 Confucius, Analects, Chap. IV.

${ }^{6}$ Ila Bhatt, The Illustrated Weekly of India (New Delhi) 24 December 1972, p. 37 .

${ }^{7}$ Ibid., p. 21 . ${ }^{8}$ Ibid., p. 8.

$9_{\text {Robert }} \mathrm{T}$. Oliver, "Introduction," in Communication and Culture in Ancient India and China' (Syracuse, New York: Syracuse University Press, 1972).

IOTopoi (對 $\theta$ ) is a form of writing biographies in Asia. It directs toward.giving a "mystic" description of the hero.

${ }^{1}$ Published in Taiwan by the Chinese (Taiwan) Publishers (1971).

12 Published in Red China by the Chinese People's. Publishers (1971).

13 Oliver, "Biography as Rhetoric," in Communication and Culture in Ancient India and China.

14 Idem, "Caste as Rhetoric in Being," pp. 31-36.

15 Nrioendra Kumar Dutt, Origin and Growth of Caste in India, 2 vols. (London: Kegan Paul, Trench, Trubner and Co., ig3i), p. 32 .

${ }^{16}$ John W. Wilson, Indian Caste, 2 vols. ed. P. Peterson, vol. I (1877), p. 13.' No publisher indicated. 
17 Arthur F. Wright and Denis Twitchett, Confucian Personalities (Stanford, California: Stanford University Press, 1962), p. 6.

${ }^{18} \mathrm{Li}$ Chien-nung, The Political History of China, 1840-1928, trans, and ed. Ssu-yu Teng and Jeremy Ingalls (Stanford, California: Stanford University Press, 1956), p. 99.

19 Oliver, pp. 12-14.

${ }^{20}$ The ideas have been taken from Arthur $F$. Wright, Confucianism in Action (Stanford, California: 'Stanford University Press, 1964), pp. 3-6.

21 Qurratulain Hyder, "The Christian Priest," The Illustrated Weekly of India (New Delhi), 24 December 1972.

22 Plato Republic, Book VII, "Cave."

23 E. A. Burtt, The Teachings of the Compassionate Buddha (New York: Mentor, The New American Library, 1955), p. 16 .

24 Tbid., p. $17 . \quad 25$ Wright and Twitchett, p. 6.
26 Said by Professor LaRay Barna, Portland State University, 1974. p. 149 .

27 Plato The Dialogue of Plato, vol. 3, Philebus,

28 Descartes, On Rightly Conducting the Reason, p. 4Ib, cited by Mortimer J. Adler and Seymour Cain in Philosophy (Chicago: Encyclopaedia Britannica, 1963), p. 157.

29 Ibid., p. 160.

30 Archi J. Bahm, "Eastern and Western Ideals: A Comparison," University of New Mexico, 1973, p. 18.

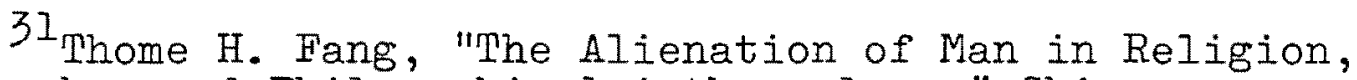
Philosophy, and Philosophical Anthropology, "Chinese

Culture, I (Taipei, Taiwan: National Chenchi University Press, 1972), p. 25.

$32_{\text {Bahm, p. } 19 .}$

33 Sung-Yuan Hsueh-An (䄈㫍案), The Scholarly Records of Sung and Yuan Dynasties, Book 30, "Ch'eng I" (Taipei, Taiwan: Shan-wu Publishers, 1970). 
${ }^{34}$ Lu Gee, Chinese History (Hong Kong: Ling Kee Book Store, 1957$)$, p. 90.

35 Ibid.

36 Sung-Yuan Hsueh-An, Book 30, "Ch'eng I," "Reason."

37 The Dialogue of Plato, vol. 1, Phaedo, cited by Descartes (reprint, Taipei, Taiwan: Wun-sing Printing Co., 1953).

38 Mencius, Meng-Tzu, Book 6, part I. Chap. 7

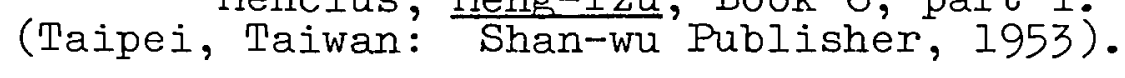

${ }^{39}$ Carsun Chang, Development of Neo-Confucian Thought (New York: Bookman Associates, 1957), pp. 27-33.

${ }^{40}$ Richard E. Porter, "Introduction," in Intercultural Communication: A Reader, eds.: Larry A. Samovar and Richard E. Porter (Belmont, California; Wadsworth Publishing Co., Inc., 1972), p. II.

${ }^{41}$ Ibid. $\quad 42$ Ibid.

43 Time, 24 June 1974, p. 64.

${ }^{44}$ Wing-Tsit Chan, Religious Trends in Modern China

(New York: Columbia University Press, 1953), p. 31 : 
CHAPTER V

\section{APPLICAT IONS}

In order to support what has been said about thought patterns and to illustrate more how these thought patterns affect communication behaviors, the following events are taken from the current reports from different countries:

\section{Event One}

In McCrea Hazlett's article, "What About Indo-American Relations?" he explains very clearly why the communication behaviors of the two nations sometimes block out understanding. He writes,

Americans and Indians share common democratic ideals but their governments have failed to establish a permanent friendship that will stand the strains of political differences.

Iincoln and Gandhiji, Roosevelt and Nehru, spoke the same language of freedom and set the same cherished goals for their peoples....

But Indo-American relations have never been at a lower ebb than they are today. It is essential for both countries to examine objectively the causes, and remove the irritants.

In the sweep of America's development, the impact of Indian thought is more important than those early trade relations. The familiar story bears repeating. One of the main strands in the complex web of American character is a strong idealism. Americans believe in ideals and believe in pursuing them practically.

This idealism found its happiest and earliest expression in the middle of the nineteenth century in Concord, Massachusetts, among a group of transcendentalist thinkers and writers. These men 
rejected the prevailing forms of Protestant Christianity and wrote and thought about the world soul and other topics not strange to Indian philosophers. Ralph Waldo Emerson was the most distinguished member of this group. He was an avid reader of Indian philosophy. The quickest way to see this relationship is to read his short poem, "Brahma."

The second most important transcendentalist was Henry David Thoreau, whose reputation has so grown with succeeding generations that he is today more widely read than Emerson himself. Thoreau's very famous book, Walden, was dedicated to persuading unhappy men to give up their attachment to possessions in order to free themselves. He was primarily a seeker, not a political activist. However, an incidental political act of his had important consequences for India. He once went to jail for nonpayment of taxes because, he said, he refused to support a government which supported slavery. His "Civil Disobedience" strongly influenced Gandhi, who wrote that it "seemed to be so convincing and trueful that I felt the need of knowing more of Thoreau." Gandhi adopted civil disobedience as a key to the resistance movement. . . These contacts between India and America, though very important, were "idea to idea" rather than "people to people." I

This writing was an example of very successful intercultural communication, not only that an Indian sage understood the nature of an American transcendentalist's thoughts; but he had made use of it to achieve something great to his nation; and vice versa, the American transcendentalist also. It was because they had more or less the same thought patterns, in a rebellious sense--negative and nonviolent protest. If both Gandhi and Hawthorne did not have such a kind of attitude, they they would not have acted in such a way. 
Event Two

Following are three articles showing the differences of attitudes toward hero worshipping between the East and the West.

After the Paris Agreement of January, 1973, the South Vietnamese threw themselves enthusiastically into replaying the history of 30 years ago. The brief, ugly decade of American involvement here was thrown off as though it had never been, and so surprised werre the Vietnamese by the sudden vacuum of authority that they immediately looked to the past to fill it. Overnight they rehabilitated the reputation of the murdered ex-President Diem and formed committees to urge the return of Bao-Dai, Vietnam's last emperor, now living in exile in France. They chose to forget that President Diem ran a police state in which people lived in terror. ${ }^{2}$

Ten years ago, on November 22, 1963, President Kennedy was assassinated in Dallas. Many see this date as the moment when American society lost its way. But Americans are quick to pull down their heroes, and they have recently been more critical of Kennedy's presidency than they were at the time of his death. . .

He had considerable faith in human reason dispassionately applied, much less-faith perhaps in human nature. He thus had a premonition of a certain fragility in the American political and social order--a premonition that no doubt fueled his determination to do things to hold that order together while there was still time. And, indeed, after his death the national policy began, it would seem, to fall apart--first the insurgencies of the Johnson years, the uprising among the young, the Woman's liberationists, the blacks, the Indians; then the corruptions of the Nixon years, the lawless White House staff, the irresponsible or complicit president, the crooked vice-President, the pervading indifferences to the laws and the Constitution.

How much did Kennedy himself contribute to the time of troubles that followed his death? Americans have a habit, not entirely bad, of pulling down their heroes rather soon after. they have passed from the scene. Within my own lifetime this has happened, for a reason, to Theodore Roosevelt, to Woodrow Wilson, to Franklin Roosevelt. It is happening 
these days to Kennedy. He is portrayed as a reckless agitator at home, a rigid and embattled cold warrior abroad, a President seductive in style but empty of substance. "Every hero," wrote Fmerson, "becomes a bore at last." Eventually history strikes a balance. 3

For the rest, he [Nehru] remained a man of rare sensitivity and compassion. A handsome man who cared much for beauty, elegance and excellence. A man who would not stoop to tricks which are every politician's stock-in-trade. Far from corrupting him, absolute power did not spoil Nehru in the least. There was absolutely nothing crude or crooked about him. Of how many men, let alone men of power, can this be said? The bad things that Nehru did or allowed to happen must not be lost sight of by any means. But the much greater good that he undoubtedly did should not be interred with his bones. 4

The individual incidents are important for showing the impact of styles of thinking and suggesting how an impasse in this area is interpreted and usually projected to the social and political human interaction. It shows that EuroAmericans do respect their heroes only when they are still alive and can contribute to the present world; whereas the Asians respect their heroes only when they have passed away. In terms of intercultural communication, if an American is so naive (the author knows this is a biașed word, but he is naive also and cannot think out another word to replace it!) to criticize the passed away heroes of the Asians, he would not be welcomed because the Asians respect their ancestors very much and believe that no one should criticize them, no matter for good or bad. Any Euro-Americans committing this mistake would not be excused easily. 
Event Three

Here is an article quoted from The Illustrated Weekly of India showing the concepts of the Christian missionaries

in India:

There are about 4-1/2 million Protestants in India. Most of them live in the northern and eastern regions. Some of our finest colleges and hospitals were established during the American and English Protestant missionaries who also played a decisive role in alleviation of such evil practices as thugee, sati, child marriage and the devadasi system. Indian Protestants carry on the tradition by active participation in relief work for people stricken by flood or famine. Their educational institutions continue to be among the best in the country. . .

Where I come from, the image of the educated Christian has always been that of the nurse, the teacher, the doctor. Nevertheless, there was almost no Christian middle class. But the poorest of Christian families were models of orderliness, courtesy and piety.

The caste pattern was fairly obvious. Sons and daughters of brahmin and other high-caste became teachers, doctors or social workers. And although many converts from the "untouchable" castes also came up in life, a faint stigma continued to attach to them.

The Christians were at one time criticized for being the by-products of British Colonialism. . .

From the very outset the missionaries faced the problem of Caste, as brahmin Converts refused to mix with those who were not twice-born. The multiplicity of languages was another problem for the missionaries. But the most difficult of all tasks was to persuade the natives that Christianity was philosophically and ethically superior to indigenous religions. . .

There came a time when many White Young men and women were fired with the zeal to go out East--to Africa, China and India--to save the soul of the heathen. Up to the middle of the 19th century a number of Englishmen labored under the belief that, in due course, Indians would see the light of reason and accept Christianity.

White missionaries started with many advantages: They were better educated, conversant with the scientific discoveries of the times and well endowed. 
They were fired with enthusiasm and energy characteristic of young nations on the rise. And they genuinely believed that God had commanded them to "civilize" the lesser breeds without the law.5

The Euro-American missionaries, advisors, consultants in Asia are sometimes deprived of the many familiar guideposts of their own cultures which allow them to act, to speak, to write without deep thinking, or without much awareness of their cultural orientations. The result is unsuccessful intercultural communication. From the example * given above, readers can see how biased and arrogant the Christian writer is, especially when he uses the terms as "evil practices," Indians could not accept them." To the writer, anything Indian is inferior to that of the West, so that all Indians should be "civilized" by them.

During the process of intercultural communication when the Euro-American is in the Eastern world, each speech or act may require planning and decision; otherwise he may not know that he has irritated technically and culturally the Asians, and thus blocked intercultural understanding. The same is true with the Asians.

\section{Event Four}

The Far Eastern Economic Review in January 1972 published an article discussing the future change for Taiwan showing the different points of view from the East and the West. 
What future change for Taiwan?

The first casualty of the Kissinger trip to Peking has been the Nationalist govenrment in Taiwan. The staunch U.S. ally for the last 20 years has been disgraced by its eviction from the U.N. with, it is believed in international levels, the traitor consent of the American government. What does this imply for the future of Chiang Kai-shek's regime and the diplomatic status of the island that he rules? Basically there are three options being discussed in the world press: a plebiscite leading to an independent state of Taiwan and the ousting of the Nationalists (Le Soir), a return of Taiwan to the administration of the mainland ( $T a$ Kung Pao), or the retention of power by Chiang regime for the infinite future, but outside the U.N.6

From this example, with the points of view. from the East and the West, one can see how different it, is to individual nations. How about to the Taiwanese themselves? If one understands the cultural orientations of them, he ought not be surprised to hear such a comment: "That is fate. Let's accept it and don't worry too much about the future changes." 
Chapter 5--Notes

${ }^{1}$ McCrea Hazlett, "What About Indo-American Relations?" The Illustrated Weekly of India (New Delhi), December 1972, pp. 8-13.

${ }^{2}$ Victoria Brittain, "What Peace Means in Vietnam?" The Illustrated London News, March 1974, pp. 27-28.

3 Arthur Schlesinger, "American Heroes," The Illustrated Iondon News, November 1973, p. 45.

4 Inder Malhotra, "Nehru--Eight Years After," The Illustrated Weekly of India (New Delhi), December 1972.

5 Qurratulain Hyder, "The Christian Priest," The IlIustrated Weekly of India (New Delhi), 24 December 1972.

Far Eastern Economic Review (Hong Kong), January 1972 , pp. 27-31. 


\title{
CHAPTER VI
}

\author{
SUMMARY
}

We need to show that we're not just skull-diggers and headhunters; one of our main tasks is to make "foreigners" comprehensive. Modern communication has reduced the size of the world to such an extent that it's no good any more thinking of humanity as consisting of "ourselves" and "those bloody foreigners" or "those blacks: those Indians!" We have to learn to communicate with them. And to do this we have to learn to understand the nature of foreignness. This is the very essence of anthropology-how people feel themselves to be different, and what reactions of dominance and aggression, love and hate, cooperation and hostility flow from the feelings of difference.1

The above was said by the most famous contemporary British Royal anthropologist, Mr. Anthony Grey. The writer used these ideas and extended them in the previous chapters of this thesis. What has been written has been intended to make "foreignness" comprehensive--so that the Euro-Americans could come closer to understanding the Indians and the Chinese, and vice versa.

The great modern European sage Albert Schweitzer said:

We know very little about any thought except our own, especially about the Indian thought. The reason why it is so difficult to become familiar with this is that Indian thought in its nature is so entirely different from our own because of the great part which the idea of what is called world and life negation plays in it. Whereas our modern European world-view (Weltanschuung), like that of 
Zarathustra and the Chinese thinkers, is on principle world and life affirming.

World and life affirmation consists in this: that man regards existence as he experiences it in himself and as it has developed in the world as something of value per se and accordingly strives to let it reach perfection in himself, whilst within his own sphere of influence he endeavors to preserve and to further it.

World and life negation on the other hand consists in his regarding existence as he experiences it in himself and as it is developed in the world as something meaningless and sorrowful, and he.. resolves accordingly a) to bring life to a standstill in himself by mortifying his will-to-live and b) to renounce all activity which aims at improvement of the conditions of life in this world.

World and life affirmation unceasingly urges men to serve their fellows, society, the nation, mankind, and indeed all that lives, with their utmost will in lively hope of realistic progress. World and life negation takes no interest in this world, but regards man's life on earth either merely as a stage-play in which it is his duty to participate, or only as a puzzling pilgrimage through the land Time to his home in Eternity.?

What Albert Schweitzer says are the basic different thought patterns between the last and the West have been discussed in the previous chapters of this thesis. It is these differences of thought patterns that interfere with understanding when humans from other cultures communicate with each other. The unawareness of the differences is the biggest stumbling block to intercultural communication. These individual culturally oriented thought patterns have permeated intö people's very natural communication behaviors. Concluding remarks of this thesis are of three roots: (1) While attending to details, the reader is likely to have forgotten that the thought patterns which seem so basic and 
traditional are the prevailing basis for either successful or unsuccessful intercultural communication; (2) Knowledge of these contrasting cultural orientations and thought patterns may be useful to people within each culture in better understanding their own culture, which is necessary in order to try to understand people from other cultures. As Bahm says :

Knowledge of these differing emphases may supply one with additional cultural riches from which to draw traits in shaping up his own unique personality. Knowledge of these differing emphases may provide insight into the problem to be faced, including cultural conflicts to be overcome, as people, living closer together on a shrinking globe, participate in the emergence of a more complicated world culture.3

(3) It is important to remember that no one Indian or Chinese or Euro-American will ever fit any of these traditional patterns exactly. But by being alert to the possibility of differences one can have a better chance of intercultural communication. 
Chapter 6--Notes

IAnthony Grey, "Anthropology Up to Date," The IIlustrated Iondon News, May 1974, p. 65.

${ }^{2}$ Albert Schweitzer, Indian Thought and Its Development (Boston: The Beacon Press, 1960), pp. 1-3.

${ }^{3}$ Archi J. Bahm, "Eastern and Western Ideals: A Comparison," University of New Mexico, 1973, p. 5. 


\section{A SELECTED BIBLIOGRAPHY}

\section{Western Works}

Alder, Mortimer J., and Cain, Seymour. Religion and Theology. Chicago: Encyclopaedia Britannica, Inc., 1961.

- Ethics: The Study of Moral Values. Chicago: Encyclopaedia Britannica, Inc., 1962.

- Philosophy. Chicago: Encyclopaedia Britannica, Inc., 1963.

Anant, Santokh S. "Self and Mutual Perception of Salient Personality Traits of Different Caste Groups." Journal of Cross-Cultural Psychology, 1, No. I (Spring 1970), 41-52.

Baeck, Leo.' Judaism and Christianity. Cleveland and New York: Meridian Books, 1961.

Bahm, Archi J. "Eastern and Western Ideals: A Comparison." University of New Mexico, 1973.

Barna, LaRay M. "Stumbling Blocks iṇ. Interpersonal Intercultural Communication." Intercultural Communication: A Reader. Edited by Larry A. Samovar and Richard E. Porter. Belmont, California: Wadsworth Publishing Co., Inc., 1972 .

Bàrnlund, Dean C. "Toward A Meaning-Centered Philosophy of Communication." Journal of Communication, 1, No. 12 (1966), 200-201.

Berlo, David K. The Process of Communication. New York: Holt, Rinehart, and Winston, 1960.

Brehmer, Berndt, et al. "A Cross-National Comparison of Cognitive Conflict." Journal of Cross-Cultural Psychologi, 1, No. 1 (Spring 1970), 5-20:

Brittain, Victoria. "What Peace Means in Vietnam." The Illustrated London News, March 1974, 27-28.

Burtt, E. A. The Teachings of the Compassionate Buddha. New York: Mentor, The New American Library, 1955. 
Bynner, Witter. Three Hundred Poems of the T'ang Dynasty. Taipei, Taiwan: Wun-Sing Books, 1955.

Carnap, R. Philosophy and Logical Syntax. London: Kegan Paul, Trench, Trubner Publishers, 1935.

Chan, Wing-tsit. Religious Trends in Modern China. New York: Columbia University Press, 1953.

Chang, Carsun. $\frac{\text { The Development of Neo-Confucian Thought. }}{\text { New York: }}$ Davison, W. Phillips. Interpersonal Political Communication.
New York: Frederick A. Prager, 1965.

De Bary, William T. The Buddhist Tradition in India, China and Japan. New York: Vintage Books, 1972.

Dodds, E. R. The Greeks and the Irrational. Boston: Beacon Press, 1951.

Dutt, Nrioendra Kumar. Origin and Growth of Caste in India. Kegan Paul, Trench, Trubner and Co., 1931.

Fang, Thome $\mathrm{H}$. "The Alienation of Man in Religion, Philosophy and Philosophical Anthropology." Chinese Culture, I. Taipei, Taiwan: National Chenchi University Press, 1972.

Feuerbach, Ludwig. The Essence of Christianity. New York: Harper and Row Publishers, 1957.

Fromm, E. Psycho-analysis and Religion. Taipei, Taiwan: Sun-chun Publishers, 1971.

Grey, Anthony. "Anthropology Up to Date." The Illustrated London News, May 1974, 65.

Hackin, J. Asiatic Mythology. New York: Thomas Y. Crowell Company, 1972 .

Haglund, Ake. Contact and Conflict. Malaysia: Berlingska Boktrycheriet, Iund, 1972. Hall, Edward T. The Hidden Dimension. Garden City, New York:

The Silent Language. Greenwich, Conn.: Premier Publishing Company, 1959 . 
Hazlett, McCrea. "What About Indo-American Relations?" The Illustrated Weekly of India (New Delhi), May 1972, 8-14.

Hyder, Qurratulain. "The Christian Priest." The Illustrated Weekly of India (New Delhi), December 1972, 6-7.

Jenson, Vernon. Perspectus on Oral Communication. Boston: Holbrook Inc., 1970.

Keen, Sam. "The Cosmic Versus the Rational." Psychology Today (July 1974).

Kleinjans, Everett. "Communication with Asia." Intercultural Communication: A Reader. Edited by. Larry A. Samovar and Richard E. Porter. Belmont, California: Wadsworth Publishing Company, Inc., 1972.

Le Soir. "What Future for Taiwan?" Far Eastern Economic Reveiw (January 1972), 27-31.

Ii, Chien-nung. The Political History of China 1840-1928. Translated by Ssu-yu Teng and Jeremy Ingalls. Stanford, California: Stanford University Press, 1956.

Luther, Disler. "The Adolescent 'Hippie' and the Emergence of a Matristic Culture." Intercultural Communication: A Reader. Edited by Larry A. Samovar and Richard E. Porter. Belmont, California: Wadsworth Publishing Company, Inc., 1972.

Malhotra, Inder. "Nehru--Eight Years After:" The Illustrated Weekly of India (New Delhi), December 1972.

Murphy, Lois and Murphy, Gardner. "Perspectives in CrossCultural Research." Journal of Cross-Cultural Psychology, I, No. I (Spring 1970), 1-4.

Nikhilananda, Swami. The Upanishads. New York: Bonanza Books, 1949.

Oliver, Robert T. Communication and Culture in Ancient India and China. Syracuse, New York: Syracuse University Press, 1972. Syracuse University Press, 1971. Syracuse, New York: 
Paul Cardinal Yupin. "Comparison Between Eastern and Western Cultures." National Chenchi University, Taipei, Taiwan. Lecture, 22 June 1973.

Petersen, James. "Lessons from the Indian Soul." Psychology Today, 6 No. 12 (May 1973).

Plato. The Dialogue of Plato.

Prosser, Michael $\mathrm{H}$. Intercommunication Among Nations and Peoples. New York, San Francisco, London: Harper Row Publishers, 1973.

Ruesch, Jurgen and Bateson, Gregory. Communication: The Social Matrix of Psychology. New York: W. W. Norton and Company, Inc., 1968.

Samovar, Larry A., and Porter, Richard E., ed. Intercultural Communication: A Reader. Belmont, California: Wadsworth Publishing Company, Inc., '1972.

Scheler, Max. The Nature of Sympathy. New Haven, Conn.: Yale University Press, 1954.

Schlesinger; Arthur. "American Heroes." The Illustrated London News, November 1973, 45.

Schweitzer, Albert. Indian Thought and Its Development. Boston: The Beacon Press, 1960.

Sitaram, K. S. "What is Intercultural Communication?" Intercultural Communication: A Reader. Edited by Larry A. Samovar and Richard E. Porter. Belmont, California: Wadsworth Publishing Company, Inc., 1972.

Stafford-Clark, David. "Seeing and Believing." The Illustrated Iondon News, March 1974, 47.

Steward, Edward C. "American Advisors Overseas." Intercultural Communication: A Reader. Edited by Larry A. Samovar and Richard E. Porter. Belmont, California: Wadsworth Publishing Company, Inc., 1972.

- American Cultural Patterns: A Cross-Culltural Perspective. The Regional Council for International Education. Pittsburgh, Pennsylvania: University of Pittsburgh, 1971.

Tagore, R. The Religion of Man. Boston: Beacon Press, 1961 . 
Wilson, John W. Indian Caste. 2 vols. Edited by

Wright, Arthur F., and Twitchett, Denis Confucian PersonArthur F. Stanford, California: Stanford University
Press, ig62.

Chinese Work.s

Chen, Li-fu (陳立夫).
Taipei, The Four Books: Explanatory

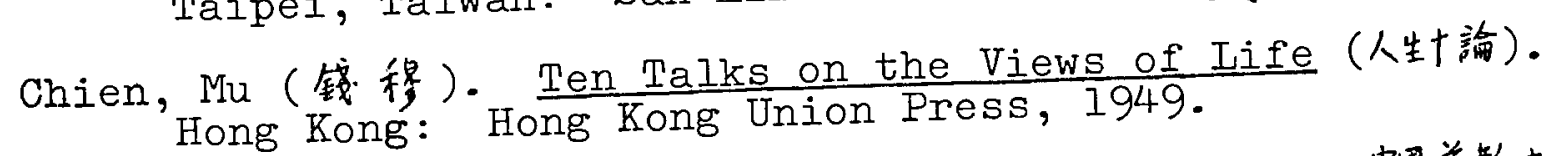

Fuh, Chyn-jia (傅著). History of Taoism in China (中圆道教史). Shanghai: Shan-wu Publisher, 1937. (商䂫印著局).

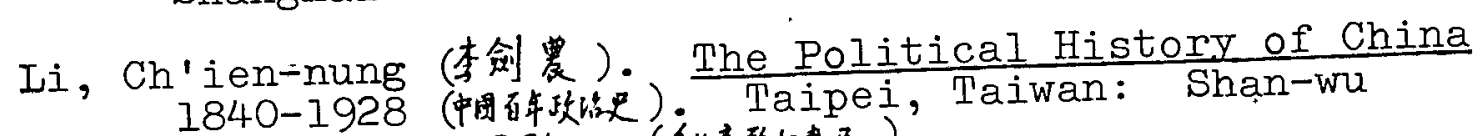

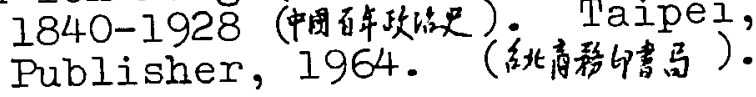

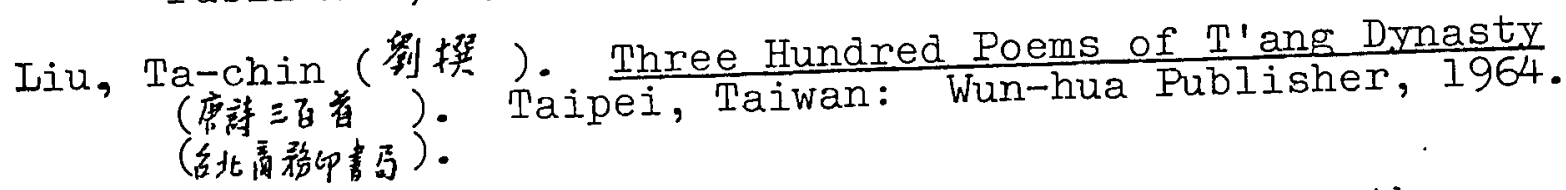

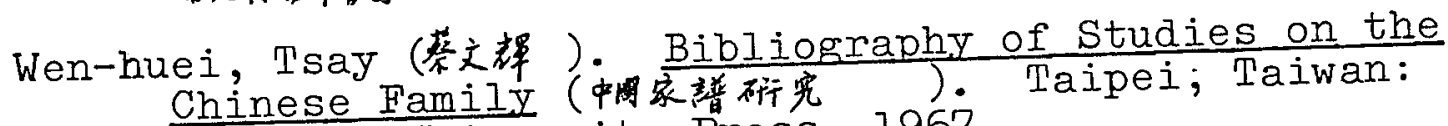
National University Press, 1967. 